Portland State University

PDXScholar

$11-4-1994$

\title{
Establishing US Military Government: Law and Order in Southern Bavaria 1945
}

Stephen Frederick Anderson

Portland State University

Follow this and additional works at: https://pdxscholar.library.pdx.edu/open_access_etds

Part of the History Commons

Let us know how access to this document benefits you.

\section{Recommended Citation}

Anderson, Stephen Frederick, "Establishing US Military Government: Law and Order in Southern Bavaria 1945" (1994). Dissertations and Theses. Paper 4689.

https://doi.org/10.15760/etd.6573

This Thesis is brought to you for free and open access. It has been accepted for inclusion in Dissertations and Theses by an authorized administrator of PDXScholar. Please contact us if we can make this document more accessible: pdxscholar@pdx.edu. 
THESIS APPROVAL

The abstract and thesis of Stephen Frederick Anderson for the Master of Arts in History were presented November 4, 1994, and accepted by the thesis committee and the department.

COMMITTEE APPROVALS:
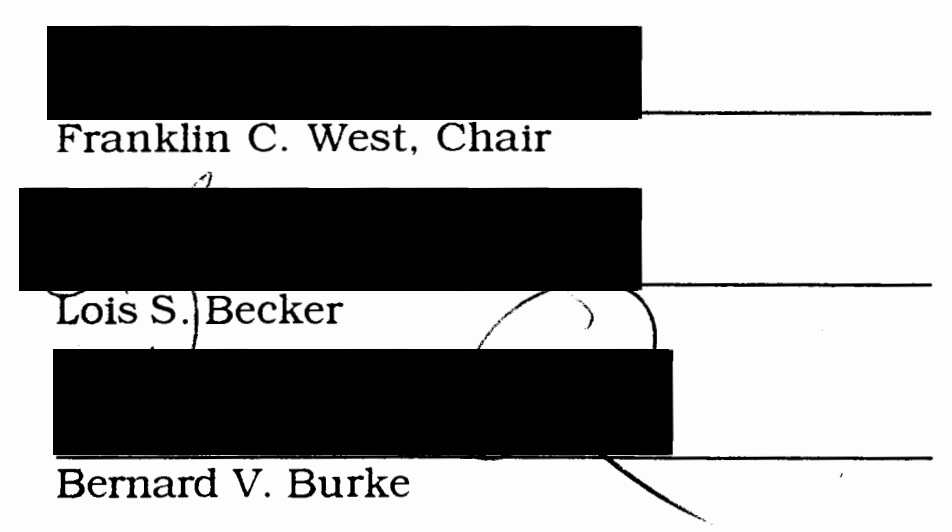

DEPARTMENT APPROVAL:

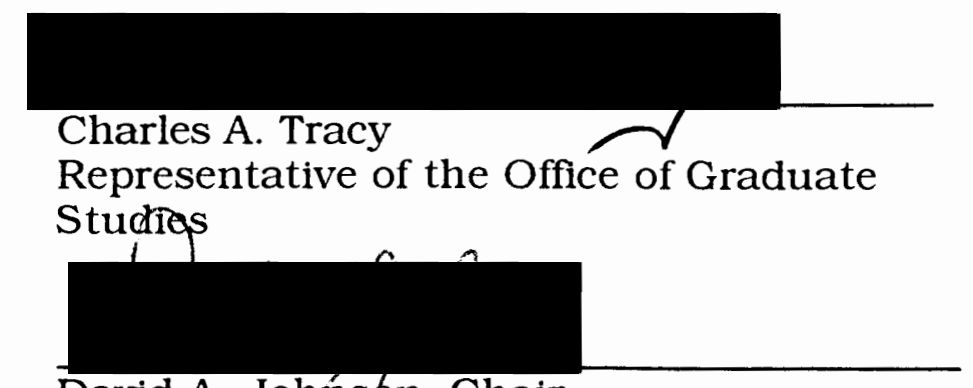

David A. Johnison, Chair

Department of History

ACCEPTED FOR PORTLAND STATE UNIVERSITY BY THE LIBRARY

by

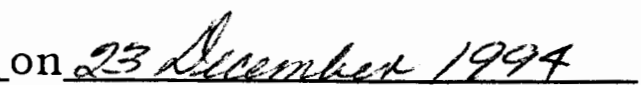




\section{ABSTRACT}

An abstract for the thesis of Stephen Frederick Anderson for the Master of Arts in History presented November 4, 1994.

Title: Establishing US Military Government: Law and Order in Southern Bavaria 1945.

In May 1945, United States Military Government (MG) detachments arrived in assigned areas of Bavaria to launch the occupation. By the summer of 1945, the US occupiers became the ironical combination of stern victor and watchful master. Absolute control gave way to the "direction" of German authority. For this process to succeed, MG officials had to establish a stable, clearly defined and fundamentally strict environment in which German officials would begin to exercise token control.

The early occupation was a highly unstable stage of chaos, fear and confusing objectives. MG detachments and the reconstituted German authorities performed complex tasks with many opportunities for failure. In this environment, a crucial MG obligation was to help secure law and order for the defeated and dependent German populace whose previously existing authorities had been removed. Germans themselves remained largely peaceful, yet unforeseen actors such as liberated "Displaced Persons" rose to menace law and order. The threat of 
criminal disorder and widespread black market activity posed great risks in the early occupation.

This thesis demonstrates how US MG established its own authority in the Munich area in 1945, and how that authority was applied and challenged in the realm of criminal law and order. This study explores themes not much researched. Thorough description of local police reestablishment or characteristic crime issues hardly exists. There is no substantial local examination of the relationship between such issues and the early establishment of MG authority. Local MG records housed in the Bayerisches Hauptstaatsarchiv (Bavarian Main State Archives) provide most of the primary sources. This study also relies heavily on German-language secondary sources. 
ESTABLISHING US MILITARY GOVERNMENT:

LAW AND ORDER IN SOUTHERN BAVARIA 1945

by

STEPHEN FREDERICK ANDERSON

A thesis submitted in partial fulfillment of the requirements for the degree of

MASTER OF ARTS

in

HISTORY

Portland State University

1994 


\section{ACKNOWLEDGEMENTS}

Original research conducted in Munich was made possible by a combined Fulbright Award for the 1993-1994 academic year consisting of a nine-month Germanistic Society of America Graduate Research Fellowship and a Travel Grant from the Fulbright-Kommission in Bonn. Many thanks go to Dr. Franklin C. West and Dawn White of Portland State University, Reiner Rohr of the Fulbright-Kommission, Dr. KarlUlrich Gelberg of the Gehetmes Hausarchiv and helpful staff members of the Bayerisches Hauptstaatsarchiv, the Bayerische Staatsbibliothek and the Institut für Bayerische Geschichte. Heartfelt gratitude goes to Prof. Dr. Jürgen and Christa Falter and family for making me feel at home. Deepest love and thanks to René for waiting. 
TABLE OF CONTENTS

PAGE

ACKNOWLEDGEMENTS . . . . . . . . . . . . . iii

\section{CHAPTER}

I INTRODUCTION . . . . . . . . . . . 1

II US MILITARY GOVERNMENT IN THE EARLY

OCCUPATION ................. 10

Origins of US Military Government . . . . 11

Military Government Personnel . . . . . . . 12

Purpose, Operation, and Planning ...... 13

Chaos and Expediency ........... 21

III LOCAL ESTABLISHMENT OF MILITARY

GOVERNMENT ............... 26

Miesbach: Military Government

Auf dem Lande . . . . . . . . . . . 27

Munich: The First Days . . . . . . . . . 35

The Fleeting Role of the

Freiheits-Aktion Bayern . . . . . . . . . 45

IV DEFINING AUTHORITY AND ASSURING PUBLIC

SAFETY . . . . . . . . . . . . . 54

Clarifying the New Order . . . . . . . . $\quad 55$

Reactivating German Police Authority . . . 62 
V LAW AND ORDER ISSUES . . . . . . . . . . 82

Capitulation, Chaos, and Crime ...... 84

Displaced Persons and Crime . . . . . . . 96

VI LAW AND ORDER ISSUES II:

THE BLACK MARKET . . . . . . . . . . . . . . 111

The Nature of the Black Market . . . . . 112

Confronting the Munich Black Market . . . 120

VII CONCLUSION .................. 130

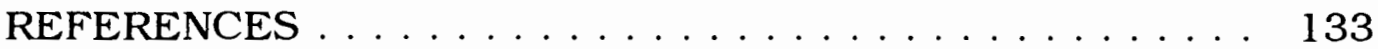




\section{CHAPTER I}

\section{INTRODUCTION}

In the fall of this year, four years after the German Wiedervereinigung, or unification, the United States symbolically ended its significant role in the occupation of Germany at a Berlin ceremony. In the same period, however, the US and its current United Nations allies find themselves in other foreign lands under chaotic conditions and complex political circumstances. In a global juggling act, US forces are obligated -- for better or worse -- to restore or establish governments, peace or both in Kuwait, Somalia, and Haiti. Even so, some argue, these selective commitments are not enough: in still other lands US forces could also be restoring "order" but are not -- yet.

A critical role of US forces these days is not to commit to a long series of campaigns of conquest, but rather to reestablish and maintain order so that new chances and changes can be created. Recently, it appears, American forces have truly become the "world's policemen." Securing law and order has become the understood mission of US forces wherever US interests are affected.

For the US Military Government detachments blazing into Bavaria on the US Seventh Army's back in May 1945, the immediate objective was very much the same as it for US authorities today. The maintenance of order and the establishment of authority were pressing goals, the re- 
establishment of a "democratic" form of government the eventual goal. The situation in 1945 was also very much different. A difficult and damaging world war was coming to a close. For years Americans had been waging war against a Germany they had learned to despise. With the German capitulation of May 1945, however, Americans were suddenly forced to administer and care for their bitter foe. On their part, Germans had endured and lost a long war at profound and devastating costs to their highly developed society. German politics, the economy, honorable and infamous institutions alike would be radically altered. National psyche, beliefs and traditions would never obey the same impulses as before. Whether 1994 or 1945 , undertaking the role of occupier or assuming that of the occupied involves severe and problematic duties.

Like its allies in other parts of Germany, ${ }^{1}$ US Military Government detachments arriving in a recently overrun area had one principal mission: to dictate the vanquished German foe. In May of 1945, US authorities arrived in the defeated and debilitated areas of Munich and Southern Bavaria and "hit the ground running" to dictate all developments and influence every initiative.

1 The British held most of Northern and Northwestern Germany, the Russians all of Eastern Germany, and the Americans Southern, Central, and parts of Southwest Germany. Free French Forces held areas in Southwest Germany. With the establishment of official occupation zones in the fall of 1945, France recelved more of Southwest German territory, including Stuttgart, where US occupation authorities had already begun to establish themselves. The US gained the Bremen enclave as an outlet to the sea in the north. The Allied zonal agreements had many minor effects on the German map in addition to the eventual significant split between east and west and elimination of vast Prussian lands. Bavaria, for example, lost the Southern Rhineland territory it had held since the Napoleanic era. 
The early occupation was a direct "extension of war" -- by preserving victory and consummating military aims. As in wartime, extreme conditions demanded that expediency and security determined actions. The immediate goals were direct and urgent. The prominent political occupation goals most recognized today were not yet clearly formulated, inevitable, or even intended. "Denazification" and "Democratization" were not foremost in the minds of US Army or Military Government officers. The Marshall Plan and the creation of a stable, economically self-sufficient Germany as a bulwark against the Communist Bloc were a long way off. The future course of the occupation would be very much influenced by the degree to which commanding authority could be established.

Still, the war had indeed ended. US MG ${ }^{2}$ was directed to modify its martial objectives in the same early stage of the occupation. MG could not "rule" as victor indefinitely. Complete control promptly gave way to "direction." For proper direction to succeed, MG had to first set up a stable, clearly defined and fundamentally strict relationship in which German officials would begin to exercise token authority under strict US supervision. US occupiers soon became the ironical combination of stern victor and custodial ruler. This status required certain responsibilities and obligations to the defeated and suddenly dependent German populace whose previously existing authorities had been removed.

For both occupier and occupied, the early occupation was a highly unstable period full of chaos, fear and confusing objectives. Every day,

2The abbreviation MG (Military Government) will be used throughout this study. 
MG detachments performed a complex juggling act with every opportunity for failure. MG officers were forced to choose between three different sets of directives. Many times detachment officers feuded with each other or collided with tactical army colleagues. Local circumstances changed almost daily. Massive redeployment began immediately after the capitulation in May and greatly complicated every Military Government detachment's ability to pursue a clear local policy. Most local German infrastructure was completely destroyed or severely damaged and required massive reconstruction simply to get the community "up and running." Germans trusted no one and feared repression daily from their American occupiers, former forced laborers, concentration camp inmates, and revenge-seeking fellow citizens. Germans appointed to posts frequently lost their positions in the face of ever more stringent political requirements delineated in the denazification directives. "Displaced Persons," the various foreign nationals liberated from forced labor or concentration camps, required immediate assistance and guidance. MG wrestled with all sorts of such dilemmas not only in Southern Bavaria, but throughout the US Zone of occupation. The problems were immense, and the need to overcome them immediate. Crucial future developments, directions and successes were being determined.

In this environment, the threat of criminal disorder posed great risks to US and German authorities. Major breakdowns of law and order could severely impede the overall progress and intended aims of the occupation. Without the proper level of stability the broad political occupation agendas understood and praised today would have been doomed to the planning stages much longer than necessary. As things 
turned out, critical criminal issues were controlled just enough to carry on -- at times just barely enough.

A major task of MG and the first reestablished German officials was providing "public safety," the control of threatening violent acts as well as theft and economic crimes. The challenges were varied and not always expected. Germans themselves remained surprisingly peaceful, but unforeseen actors rose to menace law and order. Many of the lawbreakers had experienced more than six years of brutal oppression and warfare. Among them, certain Displaced Persons turned out to be the most violent, persistent and intimidating lawbreakers. Others, such as GIs or German housewives became (for drastically different reasons) small-scale smugglers and petty operators, part of the hordes of minor black marketeers. MG's and the Germans authorities' early confrontation of these bewildering issues was in some respects surprisingly successful and in others prophetically dubious.

Using these considerations as the framework, this thesis seeks to raise and answer the question of how the occupation got underway. How did US MG establish authority and direct law and order in a given area, and what were the challenges? This study documents early MG operation in Southern Bavaria -- mainly in Munich -- and observes two general themes: 1) how MG established its own authority; and 2) how that authority was applied and challenged in the realm of criminal law and order. These two dependent themes above correspond to two general parts of this study. The first part comprises Chapters Two and Three. Chapter Two provides background on the development of MG -- planning, personnel, operation, goals -- while Chapter Three examines the 
establishment of MG control, indicates problems MG detachments faced, and illustrates how Germans were or were not allowed an early role. The second part contains the last three chapters. Chapter Four reveals how MG clarified its new order to Germans, and how MG allowed German police a role in the new order. Chapter Five presents crime issues typical of postwar chaos -- plundering, violent crimes, and the problem posed by the so-called Displaced Persons -- whereas Chapter Six evaluates the complex black market situation.

The scale of the study is restricted. I focus on a particular region, explore specific local issues, and limit the scope to a rather brief and chaotic but critical period. Historical works stressing local developments have been proven essential, and provide the inspiration for my research. Regional analyses of the Nazi period ${ }^{3}$ have shown how much local operations and events reveal about broad policy, overall reaction, and the tangible success of policy and purpose. John Gimbel's comprehensive 1961 study of Marburg 4 was one of the first works that brought this

3William Sheridan Allen, The Nazi Seizure of Power: The Experience of a Single German Town 1922-1945, rev. ed. (New York: Franklin Watts, 1984); Edward N. Peterson, The Limits of Hitler's Power (Princeton, NJ: Princeton University Press, 1968); Walter Rinderle and Bernard Norling, The Nazi Impact on a German Village (Lexington, KY: The University Press of Kentucky, 1993).

4John Gimbel, A German Community under German American Occupation: Marburg, 1945-1952 (Stanford: Stanford University Press, 1961). See also: Rebecca Boehling, "German Municipal Self-Government and the Personnel Policies of the Local U.S. Military Government in Three Major Cities of the U.S. Zone of Occupation: Frankfurt, Munich, and Stuttgart," Archiv für Sozialgeschichte, 25 (1985): 333-383; Lutz Niethammer, "Die amerikanische Besatzungsmacht zwischen Verwaltungstradition und politischen Parteien in Bayern 1945," Vierteljahreshefte für Zeitgeschichte, 15.2 (1967): 153-210; Edward N. Peterson, The American Occupation of Germany: Retreat to Victory (Detroit: Wayne State University Press, 1977); Hans Woller, Gesellschaft 
beneficial level of discernment to the subject of the US occupation. The local study can reveal many fresh aspects by following how an MG detachment performed habitually -- in spite of and according to the policy, handbooks and discourse.

Through the "lens" of local emphasis, this thesis aims to demonstrate how the process of MG was performed and how Germans were affected by it. This theme corresponds to the time period I have chosen. In the first few months of the occupation, the fundamentals of authority were laid almost solely on the local level in Western Germany. This was a critical challenging stage of incubation for modern Germany, but also for US MG, US occupation leaders and the future route of US foreign policy. In this atmosphere, Americans began to learn the lessons and study the messages necessary for assuming the decisive international role the US is charged with today. Although the MG experience throughout the US Zone of occupation shared similar traits, it was on the local level in the early occupation that the fundamentals of authority were laid.

I attempt to reveal how US MG succeeded, failed, muddled through and managed in its first days in one region of Southern Bavaria. Although I provide broader background information on my subject, I admit that some of the following narrative might appear to lack a framework to the reader unfamiliar with the occupation. At the risk of seeming episodic, the text details many spontaneous initiatives,

und Politik in der amerikanischen Besatzungszone: Die Region Ansbach und Fürth (Munich: Oldenbourg, 1968). For an insightful and dramatic personal account of local conditions, see: Saul K. Padover, Experiment in Germany (New York: Duell, Sloan and Pearce, 1946). 
unforeseen problems, practical proposals, relentless challenges, and expedient solutions, all within a very unstable period. It shows how a process was begun, not how it ended. It does not attempt to give the whole picture, but rather wants to give a representative view of the period and subject on a smaller but hopefully lucid framework. The larger political aims, goals, and decisions -- the broad strokes and the grand peaks -- are presented in suitably extensive studies. 5 These classically comprehensive analyses are unmistakably invaluable. They provide the proper framework and basis, and make investigations such as mine possible.

Part of the problem of "finding a framework" lies in the fact that this work explores many themes not much researched or described. 6 Thorough consideration of local police reestablishment, characteristic crime issues, or Displaced Persons hardly exists, in German or English. There is no substantial local examination of the relationship between

5 Americans as Proconsuls: United States Military Government in Germany and Japan, 1944-1952, ed. Robert Wolf (Carbondale and Edwardsville: Southern Illinois University Press, 1984); Eugene Davidson, The Death and Life of Germany (New York: Alfred A. Knopf, 1959); John Gimbel, The American Occupation of Germany: The Politics and the Military, 1945-49 (Stanford: Stanford University Press, 1961); Die Kapitulation von 1945 und der Neubeginn in Deutschland, ed. Winfried Becker (Cologne: Böhlau Verlag, 1987); Edward H. Litchfield and Associates, Governing Postwar Germany (Ithaca, N.Y.: Cornell University Press, 1953); Harold Zink, The United States in-Germany 1944-45 (Princeton: Van Nostrand, 1957). For emphasis on the tactical army's role in the occupation, see: Franklin M. Davis Jr., Come as a Conqueror: The United States Army's Occupation of Germany 1945-49 (New York: Macmillan, 1967); Earl F. Ziemke, Army Historical Series: The U.S. Army in the Occupation of Germany, 1944-1946 (Washington, D.C.: United States Army Center of Military History, 1975).

6 Where these issues receive any treatment at all I attempt to note accordingly in the footnotes. 
any of these issues and the early establishment of MG authority, in the rural or urban arena. There is a mountain of material to cover in these and other areas. I hope this work begins to fill some gaps.

The lack of comprehensive primary sources is a problem to overcome for such an unstable period. Copies of local MG records -microfilmed and housed in the Bayerisches Hauptstaatsarchiv -- are naturally the most useful records for much of what is explored here. The records are far from ideal, however. They are full of flaws and regularly recapitulate in imprecise terms, identifying groups and problems rather than personalities and explanations. Nevertheless, some issues in these pages can only be explored through such records. Black marketeers, for example, did not keep records of their methods, nor did robber bands generally record their exploits. Crippled by missing, imprisoned or fired officials and faced with drastic material shortages, local police were unable to maintain normally thorough records. MG records are the most inclusive sources available. The material includes not simply MG officers' observations but also the summation of material provided by Germans responsible for reporting to MG. Apart from the MG records and contemporary newspapers, I use secondary sources from German historians for the bulk of this work. I hope this approach enabled me to offer some alternative to the prevailing English-language sources. 


\section{CHAPTER II}

\section{US MILITARY GOVERNMENT IN THE EARLY OCCUPATION}

US Military Government detachments held deeply significant responsibilities and were to carry out highly problematic tasks. The early role of the MG detachment was that of strict disciplinarian and harsh policeman, but would soon evolve into that of guiding master and invaluable patron. Throughout the early occupation the MG detachment remained the source that tactical US military, Germans and Displaced Persons alike would turn to for help for a myriad of problems influenced by local, regional and international decisions and conditions. MG was created to address every possible challenge arising from the brutal war and a sometimes equally tiring occupation.

Along with the endless string of dilemmas, MG performance on every level and in every region was burdened with a succession of alterations: clashing orders from tactical commanders; changeable policies from above; alternating directives from within; conflicting personnel types; continuous personnel redeployment and scarcities, and changeable loyalties, needs and deeds from native Germans, refugees, and Displaced Persons alike.

In the early stage of the occupation, MG was most concerned with controlling the situation, and getting things to work again. The proper political goals to pursue would be honed later. The drastic conditions, 
intense pressures, unclear policies and inconsistent quality of the detachments meant that MG in a given area could vary widely in performance. Local Germans, cut off from the rest of their society, attempted at times to test the MG officers' limits and initiate their own reforms and governments. Few of these were allowed, and those that were did not last long.

This work is not a comprehensive analysis of the broad organizational and political factors influencing the US occupation of Germany. Nevertheless, suitable background on US MG is essential before turning to more specific consideration of MG's role. This chapter provides the framework for the rest of the work by offering a brief breakdown of MG's purpose, organization and general experience in the early occupation.

\section{ORIGINS OF US MILITARY GOVERNMENT}

In wartime planning for the occupation, the experience of the postWorld War I Rhineland occupation was a decisive factor. It was clear to the War Department that the "tactical," or combat troops then assigned the tasks of occupation were not well trained or suited for their role. As a result of these considerations, the War Department added to the four "classic" staff divisions in the regular army -- Personnel, Intelligence, Operations, Supply -- an agency specifically for MG. This fifth staff section, Civil Affairs, or G-5, was intended to better address the special problems that arose after hostilities ceased. The organizational foundation for this new staff was the existing administration for military 
police. The Provost Marshal General had the responsibility of training MG personnel. 1

\section{MILITARY GOVERNMENT PERSONNEL}

From 1943 on, MG and general staff administrative personnel received specific training in various schools in the US and England. Recruits for MG came from the regular army as well as civilian life. The professional military men recruited for MG generally had "little knowledge of German language, culture, or history and even less aptitude for civilian administration . . . . But they were at the top of the hierarchy." 2 Civilian recruits specially trained for MG held various professional positions in the fields of higher education, journalism, law, and labor. Despite their previous civilian or MG training, many recruits were not given positions in which they could exercise their acquired skills. Knowledge of German was preferred, but was rare among American-born MG personnel because of the lack of time necessary for preparation. $^{3}$

Two groups made up the specially trained MG officers. In one group were the technical and administrative experts. In the other group were emigrants from German-speaking areas together with first and second

${ }^{1}$ Niethammer, "Besatzungsmacht" 157-58.

2 Boehling, 334.

${ }^{3}$ Boehling 340; Niethammer, "Besatzungsmacht" 160. 
generation German-Americans. This second group acted mainly as language, cultural, and political experts and served in political intelligence, the public safety, or information control branches. Few of these men were career officers or not to attain higher ranks, 4 as the higher ranks were more open to MG officers who came from army stock but in many cases were less qualified for MG tasks.

PURPOSE, OPERATION, AND PLANNING

The initial mission of MG was limited. MG comprised a separate organization of specialists, yet in the early wartime phase of the occupation MG belonged and remained subordinate to the tactical army. Busy tactical army staffs were much more concerned with exigent military operations than unfamiliar MG objectives. In selling the incorporation of MG to reluctant combat staffs, the Provost Marshal General, Allen W. Gullion, described two restrained objectives for MG: 5

First, to help bring the war to a successful termination; second and entirely subordinate to the first consideration, to further the welfare of the people of the occupied territory .... What matters most is that the commanding general in any field of operations be given as complete control as possible over all the elements that must enter into the calculations.

During wartime operations General Eisenhower, although supreme military governor, entrusted his authority to generals commanding the

${ }^{4}$ Boehling 340.

${ }^{5}$ Allen W. Gullion (Provost Marshal General), "Military Government," Coast Artillery Journal, 86 (1943): 2, qtd. in Niethammer, "Besatzungsmacht" 159. 
various army groups. Eisenhower exercised his power only to make major decisions and to scrutinize when absolutely necessary. Nevertheless, neither the Supreme Headquarters Allied Expeditionary Forces (SHAEF), the combined English-American high command, or the Army groups directly commanded MG in the early phase. Direction of MG rested with the individual armies themselves, but they controlled MG only carelessly and inconsistently. 6

The incorporation of MG staffs in the General staff structure tempered its ability to fulfill its mission. As of March, 1944, the MG staffs served under the general staffs on the army group, army, corps and division level. Nevertheless, within this structure a network of MG special staffs, or detachments, were intended to make up for the lack of autonomy. In all counties 7 (Kreise and the rural Landkreise), cities, provinces, bureaucratic territories and states (Länder) in enemy territory, MG detachments, specially oriented in local conditions, moved in with the advancing combat troops and attempted to establish rule over its area. The immediate instigation of "indirect rule" -- installing "acceptable" Germans in administrative positions over which MG mandated -- was preferred, but in cases of complete breakdown of German administration the detachment would administer temporarily. 8

6 Hajo Holborn, American Military Government. Its Organization and Policies (Washington D.C.: Infantry Journal Press, 1947) 48.

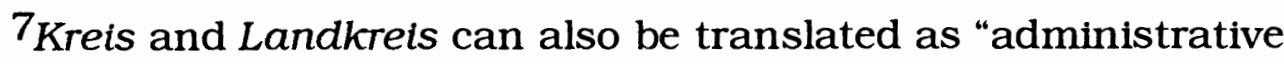
districts."

8Niethammer, "Besatzungsmacht" 159. 
In the early phase of the occupation, the main tasks of MG were to hinder the German civilian population from disrupting military operations, but at the same time to secure the interim supervision of and care for those civilians. MG was to simply "get things going again;"9 it was to apply "apolitical" methods of, above all, a practical and effective nature. The "shaping of the postwar world" would be left to later civilian administrators and politicians. 10 Consummating military objectives, establishing an "order," and setting up MG itself was the emphasis. Implementation of such methods has elicited the criticism that in this crucial period of "democratization," the chances for "real" reform were lost to a "milder," political and administrative continuity. 11

MG's mission of guaranteeing "public safety" in the early and chaotic months of the occupation -- the theme of subsequent chapters -was crucial to the success of the early occupation. Accordingly, in the early phase MG was allowed influence over the traditional army only within these critical domains of "law and order" and "military security." 12 This corresponded to the MG's purpose of assuring a stable environment for the US tactical troops, as well as for the occupied population. Since US troops were entering areas of untold ruin and

9Niethammer, "Besatzungsmacht" 161.

10Niethammer, "Besatzungsmacht" 158-59.

${ }^{11}$ Boehling 382. See also: Leonard Krieger, "The Potential for Democratization in Occupied Germany," Public Policy, ed. John D. Montgomery and Albert O. Hirschman, vol. 17, (Cambridge, Mass: Harvard University Press, 1968) 28-58.

12 Niethammer, "Besatzungsmacht" 158. 
disorder, maintaining public safety had to be one of the "first and major" alms of MG officers. 13

On the local level, MG often found it difficult to attempt the application of its aims. MG was at the mercy of tactical commanders who had little appreciation of MG's mission. Furthermore, the tactical commanders' tolerance for MG and its assignment differed greatly from unit to unit. These factors contributed to great differences in the administration and effectiveness of MG from area to area. 14 The "dualism" of tactical and MG commanders working side by side easily led to confused circumstances. The troop commander was concerned with military objectives, whereas the MG detachment officers hoped to resurrect an efficient local administration. Orders from a troop commander were often canceled by the MG detachment, or the opposite happened. As a result the local German administrators were frequently confused as to what their American occupiers wanted. 15

The MG detachments soon became independent of the tactical army. During the months following the capitulation, MG gradually broke away from the regular army structure, came under the direction of General Lucius D. Clay, ${ }^{16}$ and assumed a greater role for itself. Spring

\section{Holborn 33.}

14 Niethammer, "Besatzungsmacht" 159 . Niethammer notes that as the G-5 structure was grafted onto the tactical staff structure, troop commanders were ordered to consider MG's tasks a major objective, yet that order probably came too late to have much effect.

15 Boehling 541 .

16 Works on General Clay and the occupation include Clay's account: Lucius D. Clay, Decision in Germany (Garden City, NY: 
and Summer 1945 were months of "feverish redeployment." The enormous Allied administration of SHAEF was officially dissolved at the end of June 1945.17 The capitulation in Europe made many combat personnel available for duty in MG positions. The number of MG personnel doubled by July. 18 By September the "regime" of a US wartime occupation army had disintegrated and given way to a more autonomous system and clear hierarchy of MG. In October 1945 the now independent G-5, or Civil Affairs branch responsible for MG, was renamed OMGUS (Office of MG for the US Zone of Germany), and the regional MG (RMG) for Bavaria became OMGB (Office of MG for Bavaria). 19

The MG detachments had an ambiguous role in the early period. On the one hand, they had to maintain security for military goals and the initial care of the civilian population, which demanded strong measures, including the shutting out of any officials with links to the Nazi party; on the other hand, they were to "dominate" affairs in their area only when necessary, and to appoint competent Germans able to get things running again. This became problematic since many of the

Doubleday \& Company, 1950. See also: The Papers of General Lucius D. Clay: Germany 1945-1949, Ed. Jean Edward Smith, 2 vols., (Bloomington: Indiana University Press, 1974); Jean Edward Smith, Lucius D. Clay: An American Life (New York: Henry Holt and Company, 1990. On Clay's successor in Germany, John J. McCloy, see: Thomas Alan Schwartz, America's Germany: John J. McCloy and the Federal Republic of Germany (Cambridge, Mass: Harvard University Press, 1991).

17 Holborn 50.

18 Holborn 47.

${ }^{19}$ Niethammer, "Besatzungsmacht" 155; 168-170. 
available capable figures, having lived in a society as politicized as the Third Reich, had some sort of a "link" with the Nazi party.

The preference for indirect rule, or guidance as opposed to domination, hinted at the broader, later goals of the occupation: to not "impose" democracy, but to only impose "restraints upon those elements of the German population who would prevent democracy from being established." 20 "Democracy" would be built from the ground up, and government decentralized, according to the Potsdam Agreement of August 2, 1945. The towns and Landkreise, for example, were the first administrative units in which German self-government was established, in the American zone as well as in the other four zones. Furthermore, US combat commanders, in the early phase -- when they were in charge of the occupation -- thought it impractical, and too complicated, to attempt to control Germany by undertaking direct operating responsibilities. It was much simpler to oversee affairs administered by Germans themselves. 21

The early emphasis on an "apolitical" effectiveness was partly due to confused and ill-defined Allied policy. In 1944 the G-5, or the Civil Affairs section of SHAEF responsible for MG, began developing its own plans for MG procedure. The resulting plans, comprised in the SHAEF "Handbook for Military Government in Germany," were necessitated by a distinct lack of policy direction from Washington. G-5's formulations

${ }^{20} \mathrm{Carl} \mathrm{J}$. Friedrich and Associates, American Experiences in Military Government in World War II (New York: Rinehart \& Company, 1948) 14, qtd. in Boehling, 335.

21 Boehling 335. 
were very cautious; G-5 planners still expected final directives from Washington, but did not know how close Washington's policy would be to their own formulations. Thus, while waiting on Washington, G-5's own planners avoided political orientation and indoctrination. 22

In the same period procedures were approved by the Combined Chiefs of Staff. CSS 551 ("Combined Directive For Military Government in Germany Prior to Defeat Or Surrender") of April 28, 1944,23 consisted of the most fundamental operational and political objectives and was to be valid only until the capitulation. After the capitulation the more comprehensive and politically oriented JCS 1067 ("Directive to Commander-In-Chief of United States Forces of Occupation Regarding Military Government of Germany") would be adopted. 24 JCS $1067^{25}$ was issued in April 1945 and enumerated many of the broader policy statements later adopted by the Allied Powers in the Potsdam Agreement of August 2, 1945.

Early in the occupation MG officers stuck to the directives of both the SHAEF handbooks and CSS 551. JCS 1067 appeared only at the end

$22_{\text {Holborn }} 33$.

${ }^{23}$ Holborn 33; full text of CSS 551 in Holborn 135-43.

${ }^{24}$ Niethammer, "Besatzungsmacht" 161.

25Full text in Holborn 157-72, Documents on Germany, 19441985, Office of the Historian, Department of State: Washington, D.C., 1986,15 . For a brief piece on the evolution of JCS 1067, see Earl F. Ziemke, "The Formulation and Implementation of U.S. Occupation Policy in Germany," U.S. Occupation in Europe after World War II: Papers and Reminisces from the April 23-24, 1976. Conference Held at the George C. Marshall Research Foundation, Lexington, Virginia (Lawrence: The Regents Press of Kansas, 1978). 
of hostilities, a demanding and insecure period, and a time when MG officers were already familiar with earlier, and less intricate, rules of procedure. Furthermore, many MG officers found JCS 1067 impractical in this early, chaotic period; it had little do with diverse and dire local conditions. Many MG officers simply ignored JCS 1067 early on. 26

Nevertheless, the phase of pragmatism was short-lived. The demand for apolitical expediency gradually gave way during the summer of 1945 to the greater political and economic designs put forth by the Allied Powers, JCS 1067, as well as the heightened and better formulated role of MG. The phase of "improvisation" lasted until roughly the beginning of July. Corresponding to the disbanding of SHAEF a thick, detailed MG directive book (USFET [United States Forces European Theater] "Administration of Military Government") came into effect. This set of directives interpreted the final version of JCS 1067 for MG and detailed implementation for the various specialized MG sections. At this time the "combat phase" of the occupation officially ended. $27 \mathrm{~A}$ prescribed and precisely delineated method of "denazification" 28 replaced the early practice of simply shutting out or imprisoning Nazi party

26 Niethammer, "Besatzungmacht" 161.

27 Lutz Niethammer, Entnazifizierung in Bayern: Säuberung und Rehabilitation unter amerikanischer Besatzung (Frankfurt a. M.: S. Fischer, 1972);149.

28 Niethammer, Entnazifizierung $138 \mathrm{ff}$. The complex evolution of denazification policy -- thoroughly explored by Niethammer and in monographs mentioned above-- will not be treated here. On denazification also see James F. Tent, Mission on the Rhine: Reeducation and Denazification in American-Occupied Germany, (Chicago: University of Chicago Press, 1982). 
members according to the judgment of the local MG commander or a CIC (Counter Intelligence Corps -- army intelligence) officer. The

implementation of JCS 1067 and the substantially defined MG directives became more certain after the Potsdam Agreement, and eventually confirmed the increasingly crucial status of MG for "reshaping" Germany. 29

Over the course of the occupation, MG detachments would increasingly yield responsibilities to German authorities. MG assumed more of an advisory role. At the same time, MG, with its own independent structure, better coordinated policy.

\section{CHAOS AND EXPEDIENCY}

The first MG detachments moving farther and farther into Bavaria under the wing of the advancing US armies encountered conditions of varied and usually bewildering complexity. As discussed, the German infrastructure was in many cases fully destroyed, and local administrations abandoned. The MG units themselves varied greatly in character and competence.

MG personnel's status as members of combat units required them to employ "elasticity" and "effectiveness," two of the most important organizational principles of the advancing US combat troops. For the smaller MG units above all, elasticity meant self-reliance and the ability to arrive at decisions quickly and without advice from above.

29Niethammer, "Besatzungmacht" 170. 
Effectiveness was the "apolitical" emphasis on the immediate, pragmatic achievement of MG and military goals. 30

It can be argued that MG simply enjoyed neither the time nor resources to execute anything but the most pressing tasks. Ambitious and thorough political reform, or the strict reliance on "policy" could hardly have been foremost on MG officers' minds. Demands on MG included the following: 31

... Restoring lines of communication .... discovering German resources useful to the Allied war effort, maintaining public safety, taking measures against epidemics, etc. High priority had also to be given to lending immediate assistance to United Nations nationals, of whom more than six million were expected to be encountered in the Western Zone of Germany. In addition, property of the Allies or of the United Nations held or robbed by the Nazis was to be taken into custody.

Furthermore, although MG personnel increased, the amount of personnel available to complete such overwhelming jobs was still relatively small. Before VE-Day, only 7,500 officers and enlisted men comprised MG in all of Germany. 32

The establishment of MG in many areas was marked by confusion, varied inventiveness, and sometimes scandal. MG teams and detachments had been "pin-pointed" for specific areas and districts. Yet the individual units often found themselves in regions unknown from preparations, and the units' ability to act with decisiveness was greatly tested: "These were the days in which any central direction of [MG]

30 Niethammer, "Besatzungsmacht" 161.

$31_{\text {Holborn }} 33$.

32 Holborn 34. 
operations could hardly be attempted and the officer in the field had to find his own solutions." 33

The complete breakdown of the German infrastructure, communications, and government increased the helplessness and isolation of the local German community. In this situation many a MG commander became the "lord" of his area, a situation that allowed him much leeway for reaching effective solutions. 34 The chaos sometimes led to interestingly dubious situations. Such circumstances were much more pronounced in the rural areas and smaller towns than in the large cities, where the detachments had better information and more contact with higher-ups and central posts.

Many MG commanders took over their area with pronounced zeal and pride, hurried to set up the minimal administration and infrastructure necessary, and attempted to build up their Kreise into a functional unit capable of sustaining itself. This sometimes occurred at the expense of a nearby "rival" Kreis and a competing MG officer. This brand of "enthusiasm" often resulted in the phenomenon of the Kreiskönige (the "kings of the Kreis"): MG commanders who consolidated their area without consideration for greater needs or common policy.

Eager MG officers sometimes hurriedly named to chief positions Germans they trusted or were advised to rely on. Consistent throughout the US-controlled areas was a naive dependance on recommendations of

33 Holborn 34.

${ }^{34}$ Niethammer, Entnazifizierung 138-139. 
Catholic Church authorities. ${ }^{35}$ In many cases figures given responsibilies turned out to be controversial or unacceptable in respect to military security and political reliability. Many "criminal types," or simple charlatans found their way into high posts by, for example, simply claiming an anti-Nazi stance, a needed skill, or playing upon the innocent outlook of some MG commanders. The professional competence of local German candidates was a distinct advantage, as was English language ability. 36 Other characters were installed and supported fully, only to be identified as "big Nazis" and lose their positions days later. In the confusion, some opportunists were reported to $\mathrm{CIC}, 37$ some were not.

Ultimately, it was the mission of tactical troops to consummate the defeat of Germany in accord with military objectives, and the responsibility of MG to rebuild local German structures in agreement with increasingly political aims. In the first months of the occupation however, chaotic conditions demanded that these two distinct goals would be combined to a certain extent, even when tactical commanders

35Niethammer, "Besatzungsmacht" 161-166; Niethammer, Entnazifizierung 138-143.

36 Niethammer, Entnazifizierung 141. English was the "official" language during the occupation: all written material pertaining to matters overseen by MG had to be in English (Chronik der Stadt München, ed. Wolffram Selig, [München: Stadtarchiv, 1980] 59).

37 Niethammer ("Besatzungsmacht" 162) notes that various military intelligence groups existed in this period. They were being redeployed and or absorbed into other agencies, but the status of many intelligence personnel was unclear. Many agents simply stayed on in a territory and served at their own initiative until their future was clarified. Such figures contributed to an intelligence rivalry that led to uncoordinated and irregular data. 
lost influence. Furthermore, early occupation policy was incongruous and left many local MG detachments to reach their own conclusions as to the manner in which military government should establish itself.

In this environment, dilemmas and errors were unavoidable. Nevertheless, whatever the policy or predicament, in the first months of the occupation, the establishment of an "order" was a crucial, imperative job for MG to perform. The occupation agenda could not progress without the assurance of relative stability. Under these circumstances, the assurance of public safety .- of law and order -- became a fundamental element of MG control. 


\section{CHAPTER III}

\section{LOCAL ESTABLISHMENT OF MILITARY GOVERNMENT}

Advancing into Southern Bavaria in mid-April 1945, US forces of the Seventh and Third Army encountered a few final moments of serious fighting. A bloody four-day battle for Nuremberg destroyed what was left of an already crippled city. 1 Nevertheless, the pace at which US forces covered ground hinted that the war would soon be over. On April 23, the Seventh Army's 10th Armored Division took twenty-eight towns in a single day. "Pinpoint" MG detachments, those specifically trained to govern a particular area, were in many cases moving in on the same day

as the combat troops. ${ }^{2}$ Developments were moving fast, despite what turned out to be needless caution exercised by US forces entering the notorious "last redoubt," or Alpenfestung -- the rugged Alpine areas south of Munich believed to be prepared by Nazi diehards for a vicious last stand. ${ }^{3}$ As it turned out, US combat troops were not put to any great test in Southern Bavaria.

1 Ziemke, Army 247.

2Ziemke, Army 249.

${ }^{3}$ Both Allied leaders and Nazi leaders were duped by widespread belief in the invincibility of the Alpenfestung. Allied planners chose to follow their fears instead of intelligence facts, while Nazi leaders ignored the facts and embraced the rumours of the final stand in the Bavarian Alps. The myth of the "last redoubt" is chronicled in: Rodney G. Minott, 
For local MG detachments, however, many great challenges were just beginning. MG detachments began the arduous task of establishing themselves in a given area and setting up local authority. Events in the Bavarian capital of Munich described below -- and in subsequent chapters -- illustrate issues indicative of the early occupation, but also contrasts to the norm. A brief account of the situation in Landkreis Miesbach serves to further reveal disparities in readiness among MG detachments. Lastly, depiction of the fleeting, problematic Freiheits-Aktion Bayern resistance movement reveals an unexpected challenge to US occupiers.

\section{MIESBACH: MILITARY GOVERNMENT AUF DEM LANDE}

Various standards of MG implementation can be seen in the situation in rural areas and smaller towns. There are many similar examples from the reports of rural Kreis-detachments. ${ }^{4}$ The following MG accounts from Kreis Miesbach clearly depict the irregular implementation of MG. In comparison with the Munich situation detailed in the rest of this work, this brief summary of Miesbach MG reveals how completely different a detachment could perform in an area just a few miles from Munich.

The Fortress That Never Was (New York: Holt, Rinehart and Winston, 1964).

${ }^{4}$ BayHStA, OMGUS Annual, Monthly, and Weekly Detachment Reports. 
The rural Landkrets capital of Miesbach was itself quite different from the Munich metropolis, and gathered far less attention. The Miesbach MG detachment was clearly not nearly as prepared or suitably staffed for its mission as the highly capable and informed Munich MG detachment. MG reports for Miesbach also serve to demonstrate how MG authorities judged their own performance.

Some of the developments described exceed the period this study emphasizes but are worthy of brief mention, as Miesbach, like many "insignificant" areas, lived with controversy well after the beginning months of the occupation.

Miesbach is not well known and deserves an introduction. Miesbach is a typical Landkreis just south of Munich, and lies in the passes between the Alpine foothills and the Bavarian Alps. As it is today, the town of Miesbach was in 1945 Kreisstadt, or capital of the county (thus sharing the same name as the Landkreis), as well as the chief market town in the Kreis. It retained all the main government offices and courts. The Landkreis was and is today a popular German resort area. In 1945 the Landkreis was overwhelmingly Catholic: 54,356 inhabitants were Catholic, 8,549 Protestant, and 1,872 of other religions. The town of Miesbach was best represented by employees of industry and handicrafts, the Landkreis by farmers. Trade and handicraft were an old tradition there, as Miesbach allegedly once profitted from a Roman Road. 5

5BayHStA OMGB(Y) 10/51-3/2, "Description of a Landkreis" 4-9. A note on MG documents: "BayHStA" denotes the Bayerisches Hauptsaatsarchiv and "OMGB" Organized Military Government of Bavaria. "( $\mathrm{Y})$ " is an internal designation of the Bayerisches Hauptstaatsarchiv; the numbers stand for number, box, and folder and 
Landkreis Miesbach was known during the war as the "Nazi air-raid shelter." Many party members, military men, and industrialists moved their families there during the war and remained thereafter. 6

The war inflicted little devastation to the Kreisstadt Miesbach but much to the Landkreis in general. ${ }^{7}$ As was the case in many rural Bavarian Landkreisen, a major problem in Miesbach was the arrival of refugees. $18.5 \%$ of the 66,547 inhabitants of the Landkreis in 1945 were refugees who had never resided in Bavaria before the war. Many more were flooding in from the Munich area. Furthermore, 3,228 POWs native to the area had not yet returned. These numbers reveal that Miesbach was representative of large parts of rural Bavaria which did not suffer great damage to housing; 8 in the case of Miesbach the increases in refugees absorbed housing formerly devoted to the tourist trade, and Army requisitioning absorbed other spaces. 9

A MG team sent in 1947 to investigate occupation conditions in Landkreis Miesbach found the situation unfortunate but typical. Investigations held there, "if probed to equal depth would reveal similar conditions elsewhere."10

are set apart accordingly. Where page numbers are not given there were none in the reports.

${ }^{6}$ BayHStA OMGB(Y) 10/92-1/25, "Investigation of Landkreis Miesbach."

7BayHStA OMGB(Y) 10/51-3/2, "Description" 5.

8BayHStA OMGB(Y) 10/51-3/2, "Description" 8.

9BayHStA OMGB(Y) 10/92-1/25, "Investigation." 
What did the occupation authorities find improper in Miesbach? In areas such as Miesbach the phase between the end of combat operations and the establishment of MG was often thoroughly confused. Around the time of the German capitulation the MG detachment intended for Miesbach was held up in another nearby Kreis, Bad Aibling. It was forced to serve there for a brief time because tactical forces would not give up the Miesbach area to the specially trained MG detachments. 11

The original detachment did assume responsibility for Miesbach, but only on May 16, 1945, over a week after the capitulation. 12 Who was in charge at that time is unclear. Operations in this first week were very chaotic, dangerous, and somewhat scandalous, according to this telling report on Miesbach from the week of May 13-20:13

Public alarmed over Army police permitting SS officers and a limited number of enlisted men to remain armed with some freedom. Three civilians shot (one a CIC informant, fatally) by such elements. Troops under command of German General von Hahn,

10BayHStA OMGB(Y) 10/92-1/25, "Investigation." The file of a CIC investigating team in Miesbach dated December 1945 (BayHStA OMGB(Y) 10/92-1/5) was labelled "restricted" and thus unavailable to this writer. Nevertheless, the later investigating team quoted here concurred (10/92-1/25, "Investigation") with the restricted findings of the CIC team.

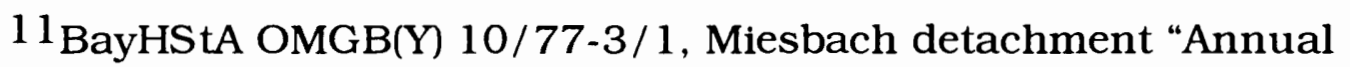
Historical Report" 1945/46 (hereafter: Miesbach AHR) 1. The reasons for this are unclear. Nevertheless, the decision was presumably a strictly operational one -- as of May 1 the US Seventh Army's advance had not fully incorporated the Miesbach area (Dieter Wagner, München '45 zwischen Ende und Anfang, [Munich: Süddeutscher Verlag, 1970] 36).

12 BayHStA OMGB(Y) 10/77-3/1, Miesbach AHR 1.

13BayHStA OMGB(Y) 13/142-1/7, Weekly MG for Munich Report (hereafter MG Weekly), May 13-20, 1945. 
who has complete freedom of movement. It is asserted he repeatedly stated in addressing his men that the war is not lost and another German Army will be formed.

The Miesbach detachment was initially commanded by Major Louis L. Haupt ${ }^{14}$ and consisted of six officers and eleven enlisted men. This original detachment was trained in Shrivenham, England, and prepared further in Civil Affairs branch centers in France and Belgium. 15 The detachment did not last long in its original state. It went through countless changes of personnel; 16 a reflection of the massive redeployment and demobilization after VE-Day.

There was clear friction between the two noted "styles" of MG officer. A compelling passage written by a Miesbach MG officer reveals how one officer viewed the effects of the "duality" of MG personnel. If his judgement is accurate, the constant changes surely affected the ability of the unit to perform: 17

Many officers and enlisted men have worked for this Detachment with varying proficiency. It is interesting to observe that many of the officers and Enlisted Men coming to the Detachment fresh from tactical [combat] units have done more efficient and more honest work than those trained for months in ECAD [European Civil Affairs Division] schools. The series of pools in which many

14 BayHStA OMGB(Y) 10/77-3/1, Miesbach AHR 1. Useful information on all but the major MG officers is unfortunately unavailable to this researcher.

15 BayHStA OMGB(Y) 10/77-3/1, Miesbach AHR 1. The author of the report notes (1) that no member of this detachment personnel "had any actual experience in Military Government."

16 BayHStA OMGB(Y) 10/77-3/1, Miesbach AHR 1.

17 BayHStA OMGB(Y) 10/77-3/1, Miesbach AHR 3. The name or background of the author is not accessible. 
specialized Military Government Officers were forced to stagnate over a year was as vicious a system as can be conceived: there is hardly a man who has passed through it who has not given concrete evidence of demoralization in the most exact sense of the word. The long sterile inactivity, the theoretical half fish, half fowl military training, killed all enthusiasm and interest in the officers and men, and many became subject to a complete moral breakdown. In the field, where the best results can be obtained by a strict application of directives issued by higher headquarters, officers and men trained as tactical troops to obey and implement orders often accomplished the objectives of Military Government more completely than by officers trained out of mind on undigested material who have decided that they know better than the directives....

The author of this passage most likely came to MG from the ranks of the tactical army.

Common in the Landkreisen was a lack of what MG considered acceptable, competent Germans to head posts. $18 \mathrm{~A}$ look at the succession of men holding the title of Miesbach Landrat, the head of the Landkreis administration, reveals the problems MG faced in finding suitable administrators and identifying suspect ones. Shortly before US troops arrived in the area, Frick, the last Third Reich Landrat (and son of the Minister of the Interior who preceeded Himmler), committed suicide. His deputy took over but was promptly removed by the detachment. A pre-1933 Landrat, von Wehner, remained in office until August 1, 1945, but "his competence and pleasant nature alone" could not hold him in office, since "his past was too damning:" He had been a senior civil

18 This work does not consider in great detail the political aspects of MG's reluctance to empower the sudden glut of "anti-Nazis," or the controversial Denazification process. Nevertheless, both themes will be referred to in the following sections on the Freiheits-Aktion-Bayern and the reestablishment of German police. On the subject of German administrative continuity and the possibility of reform, see Boehling 333 . 383. 
servant from 1927 to 1944 , a Wehrmacht major and served as Military Governor in Belgium during the war. He was succeeded by Leopold Schindler, who had no compromising associations with the Nazi party. At first he seemed excellent but then it became clear that he was both "paranoiac and a psychopathic mythomaniac." He was finally removed in May 1946, "to the relief of the public." A KPD (Kommunistische Partei Deutschlands) member, Reith, held the position until Baron von Schoen, former German Ambassador to Chile, was elected by the Kreistag. 19 This election was disapproved by MG, and Reith assumed the position again, but temporarily. 20

The detachment "had the same problems [as] in many towns and Kreise[;]. . . many MG officers were flattered by competent officials who nevertheless had a NAZI past and were reluctant to let them go." 21 The 1947 investigation of Miesbach conditions found that: 22

. . . Military Government in Miesbach lacked judgement, intelligence and impartiality -- from the beginning. This is equally apparent to the present team. The records reveal superficial investigations and approvals of [local German] MG employees and of local German government officials, and careless enforcement of MG policies.

After preparing over 150 files on individuals assigned positions by MG, receiving over 200 intercepts and conducting numerous interviews, the 168).

${ }^{19}$ The first local elections were allowed on May 26, 1946 (Chronik

${ }^{20}$ BayHStA OMGB(Y) 10/77-3/1, Miesbach AHR 5-8.

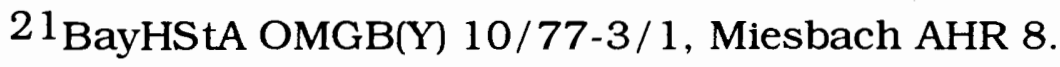

22 BayHStA OMGB(Y) 10/92-1/25, "Investigation." 
investigators were "favorably impressed" with only four individuals. The MG commander was ultimately responsible: the team disclosed that the "negligence, malfeasance and unfitness" of German officials approved by MG "should not have escaped attention by the series of M.G.O.'s ([sic] Military Government Officers -- in this case the commanding MG officer) at Miesbach."23

In Miesbach the practice of indirect rule was fraught with difficulty. The patterns the team criticized were set in motion from the beginning of the occupation, a time when any communication with Germans -- apart from giving commands -- was forbidden. A nonfraternization policy was in effect under the simple justification that "all Germans are Nazis." 24 However, in Landkreisen such as Miesbach, the "cooperation" between occupier and occupied appeared too amiable for visiting MG authorities, and for detachment insiders as well. The author of the Miesbach detachment's "Annual Historical Report" felt it necessary to add this summary of the situation: 25

It has been proved over and and over again that the officer who is lulled into confidence by a surface obsequiousness is forgetting an essential fact: no people loves or trusts or essentially wishes to help the power that occupies it.

23BayHStA OMGB(Y) 10/92-1/25, "Investigation."

${ }^{24}$ Boehling 341-343. Boehling (342) points out that: "The nonfraternization directive did not help the incoming MG detachments in making their decisions about which Germans to appoint to administrative posts, nor did it encourage anti-Nazis who might have been interested in working with the Allies constructively toward restoring democracy."

25 BayHStA OMGB(Y) 10/77-3/1, Miesbach AHR. 
The investigators from $\mathrm{CIC}$ concluded by recommending numerous dismissals of Germans in positions high and low. Regarding the detachment itself, the team did not want to "minimize the poor inheritance bequeathed to the present MGO by earlier Military Government officers." Nevertheless, the team found the MGO "little better endowed with the qualities of impartiality and judgement than his [manyl predecessors," and recommended his immediate replacement. 26

It is evident that the Landkreisen dilemmas characteristic of the first days were not resolved quickly. Of course, as touched upon earlier, the need for military security and stabilization of chaotic conditions made the application of political reform and purging in the first days only secondary in importance. In Miesbach political cleansing did not seem to become as important as it was supposed to be later. Naturally, the Miesbach example is not indicative of MG in general, nor is it a judgment of MG in general. It does, however, demonstrate the difficulties MG faced when dealing with local conditions and performing its tasks under constant changes of command and in isolated areas.

\section{MUNICH: THE FIRST DAYS}

Munich, of course, was definitely not Miesbach. The Bavarian capital held much significance -- not only because of the city's status as the Hauptstadt der Bewegung ("Capital of the [National Socialist] Movement") in the Third Reich, but also as a prominent Großstadt. The

26 BayHStA OMGB(Y) 10/92-1/25, "Investigation." 
appointments and responses of Munich MG had greater significance than anywhere else in Bavaria. Munich MG most directly expressed the intentions of the RMG for Bavaria. Without German administration on the Land (state) level, many of the responsibilities and measures MG in Munich held or oversaw sufficed initially as Land-wide ones. 27

Munich MG was well-prepared for its important role. The unit was better trained, informed and staffed than the typical MG unit. The Munich detachment was formed in England in 1944. After scrutinizing relatively detalled information on Munich area conditions and known figures, the unit formulated a plan of feasible operations. Since Munich had better, more specifically trained detachment personnel than the other US Zone cities, as well as more pertinent background information, it was easier in Munich to put theory into practice. Part of the reason for this lay in the fact that US forces took Munich so late -- there was more time to learn about conditions from Germans recently living there, and the detachment was able to learn from other detachments' problems. 28 In any case Munich's status as the birthplace of the Nazi movement demanded special MG attention. 29

The city was taken almost without any resistance. In the early hours of April 30, around 2:00 a.m., a forward US unit, supported by

\section{Wagner 158; Niethammer, "Besatzungsmacht" 177.}

28 For description of how the situation in the first city occupied by US troops, Aachen, influenced later MG practice, see Niethammer, "Besatzungsmacht" 172-177.

${ }^{29}$ Boehling 358-359: " . . . the retired [Munich MG commander] Keller wrote in 1959 that 'we knew Munich better than we did our own homes." 
armor, was able to reach the Prinzregentenplatz east of central Munich. They came under only sparse, uncoordinated fire from civilians which the troops quickly located and disarmed. The unit's goal was to set up a command post at a specific, indeed symbolic spot nearby: Hitler's private Munich residence in the Regentenstraße. They took this without resistance. 30 The main advancing troops experienced few skirmishes. The Third, Forty-Second, and Forty-Fifth divisions of the US Seventh Army reaching the outskirts of the city encountered only small, sporadic groups of Waffen-SS soldiers. Pasing, a significant suburb west of the central city, was occupied by $8: 15$ a.m.. 31

The official surrender of the city was an initially confused but basically routine undertaking. Between 1:45 and 2:00 p.m. on April 30, a US reconnaissance unit riding in a jeep found the streets uncannily quiet, and continued until reaching the Marienplatz in front of Munich's Rathaus (city hall). A huge crowd of just released POWs and Münchner 32 cheered them, but after a few minutes the unit pressed on. An hour or so later another probing US jeep, this one from the Information Control Division (ICD), stopped to observe the curious, spirited crowd on the

30 Wagner 126-127: the unit immediately took an inventory of the Führer's flat. Apart from a bust of Geli Raubal -- Hitler's niece and once alleged lover -- twelve autographed editions of Mein Kampf were the most notable finds.

31 Wagner 128.

32 Niethammer ("Besatzungsmacht". 176) notes that large sections of the population greeted the Americans' arrival as the "final blow" liberating them from tyranny and war ("Der Einzug der Amerikaner wurde in breiten Schichten der Bevölkerung als befreiender Schlußstrich unter Gewaltherrschaft und Krieg empfunden"). 
Marienplatz. The occupants of this second jeep also left shortly thereafter to resume their inspection. Remarkably, the Munich official ordered to stay in the Rathaus and handle the surrender, Dr Michael Meister, 33 claimed to have missed both episodes from his location inside the Rathaus. The "official" Munich capitulation was finally arranged later in the day, and took place in a private Munich residence between an unidentified US General and Meister. 34

Early in the morning of May 1, the Munich MG detachment arrived at the Munich Rathaus to begin operations. The detachment was headed by Lt. Col. Walter H. Kurtz and his assistant Lt. Col. Eugene Keller, Jr. Concerning the Munich MG commander Kurtz, visiting MG observers noted the following: 35

${ }^{33}$ Because of his English ability, Meister, Director of the Rechtsabteilung im Ernährungs- und Wirtschaftsamt, was ordered by a representative of the Nazi-Oberbürgermeister Fiehler to remain in the Rathaus so he could officially surrender the city (Wagner 134).

34 Hans-Günter Richardi, "Bejubelt -- doch von der Geschichte übersehen," Süddeutsche Zeitung [Munich], 8 Oct. 1993: 47. This recent article refutes the long-held assumption that the leader of the second US unit to pass over the Marienplatz, Ernest Langendorf, a German native serving as an ICD officer, was actually the first US "liberator." Furthermore, the article reveals that the commonly documented surrender of the Munich Rathaus (in Boehling 358; Chronik 42) is false. The insufficient official history of Munich MG (US Army Historical Division, Headquarters European Command, Military Government in Munich 1945-1947, vol. 1, Special Studies Series 3, [N.p.:1951] 1) states only that "[Munich] surrendered on the evening of 30 April to Lieutenant General Wade H. Haislip's XV Corps.

35BayHStA OMGB(Y) CO/451/2, Operations Report of Munich MG (hereafter: Op. Report), July 8, 1945, 28. Unfortunately little is known about Kurtz. His name is not usually mentioned in renditions of the Munich occupation. Niethammer ("Besatzungsmacht" 177), for example, simply lists Keller as the "MG commander" (MG-Chef). Kurtz 
Lt. Col Kurtz, in command, is an able and cool headed officer, a good organizer and administrator, and with a clearer definition and a more general understanding of his authority by the local commanders and the German civil authorities ... . [Kurtz] can be counted on to turn in an excellent performance.

Kurtz's time in Munich was short, however: on September 27, 1945 he died as a result of an unusual accident. He was struck by a falling stone from the Rathaus. 36 Thereupon Keller became Munich MG commander. 37 Keller, an engineer by training, spoke German because of Alsatian ancestry and personally made many of the most important early Munich contacts and gave out most instructions. 38

Successful control of the largest city in the US Zone of Occupation demanded a special detachment. In Munich the internal problems between tactical and MG detachments do not appear to have posed as many problems as elsewhere. MG detachment officers reportedly had their specialized sections "well in hand," were "competent" and "experienced" officers who were given positions for which "they seemingly

played an effective, yet "behind-the-scenes role," and left most "observable" tasks for assistant Keller to handle personally -- presumably due to Keller's language abilities -- giving the impression that Keller was the highest-ranking MG officer from the beginning (Boehling 360-61).

36 BayHStA OMGB(Y) CO/445//1, Operations Report on Military Government Detachment No. F-213, SK Munich (hereafter: Op. Report), Dec. 19, 1945, 2; Chronik 67.

37BayHStA OMGB(Y) CO/445//1, Op. Report, Dec. 19, 1945, 2. Maj. David R. Blossom became Keller's assistant. By then Keller and Blossom were the only original officers serving with the detachment; they were assigned to Munich MG on Sept. 18, 1944 (2).

38Boehling 360-61. 
are best qualified." They were "very serious in their sense of responsibility and the necessity for finishing the job and not running out on it."39 Nevertheless, MG reports do reveal some common dilemmas brought on by the many personnel changes and scarcities resulting from redeployment and MG reorganization. 40

Some of the greatest challenges to Munich MG lay in restoring the necessary city infrastructure -- communications, fire services, utilities, etc. -- crippled from years of bombing: 74 Allied bombing raids had struck Munich between 1940 and 1945, dropping 3,519,450 bombs of various kinds. 6,632 persons were killed, 15,800 wounded. 300,000 residents were homeless, 81,500 dwellings destroyed. Ninety percent of the historic Altstadt was flattened. 41 Despite Munich's lack of industrial targets, the city's reputation as the well of Nazism made it a required target for Allied bombers. 42 Untold amounts of rubble covered the city. Confronted with the chaos, the Munich MG's well qualified sections began to apply their specialized training with critical expediency, according to MG reports: 43

The first days of the occupation were extremely trying ones with everyone in Military Government striving to get his "feet on the ground" and create some measure of order out of the chaos and confusion which existed. Despite the chaotic conditions, [the

${ }^{39}$ BayHStA OMGB(Y) CO/445//1, Op. Report, Dec. 19, 1945, 2.

40BayHStA OMGB[Y] 10/78-1/4, Munich detachment Annual Historical Report 1945/46 (hereafter: Munich AHR]), 3.

$41_{\text {Chronik }}$ 42-43.

42Ziemke, Army 253.

43BayHStA OMGB(Y) 10/78-1/4, Munich AHR 2. 
Munich MG detachment] began to function immediately . . . . a mess was quickly established, the operation of the message center commenced, .... the necessary proclamations were posted, control of the fire dept. [achieved] . . . by the 8th of May the hydro-electric system was again functioning, public works and utilities was [sic] established, banks were closed, a displaced persons office was opened and on the 17th of May street car lines were again in partial operation ....

In appointing Germans -- and practicing indirect rule -- Munich MG officers demonstrated a further pragmatism. MG, as elsewhere, had in this period the power to cause a permanent breach in the continuity of German institutions and "thereby to alter the fundamental conditions of German social and political life." 44 The detachment, however, relied on "acceptable," competent, largely pre-1933 "established" figures. The Catholic church played a notable role in influencing early MG personnel decisions. Kurtz and Keller were both identified as "fanatically Catholic," and on Kurtz's initiative Keller immediately contacted the prominent Cardinal Michael Faulhaber for advice. 45

Better preparations and information allowed Munich MG to practice more stringent methods of Nazi "cleansing" than in many areas. Yet MG avoided the chance to implement profound changes. In this period Munich MG operated according to a prevalent two-step plan: MG only shut out the worst Nazis, to bide its time in finding suitable replacements. In this manner the true purging -- according to formulated goals of later "denazification" -- was postponed 46 so that the practical,

44Krieger 56.

45 Boehling 359.

46 Niethammer, "Entnazifizierung 142. 
pressing tasks of MG could be accomplished. Indeed, a rough "moratorium" existed more or less in most areas until July 1945: until full establishment of MG, reestablishment of local administration, and the implementation of the ban on political parties. 47 By late summer the demands of the elaborate denazification apparatus began to take precedence over other matters.

A brief look at a couple of the first German officials appointed reveals the "cautious" orientation. Upon arrival the first choice for Munich Oberbürgermeister (henceforth $O B$ ) was not to be found. Keller thus appointed 48 the first seemingly competent official he met in the Rathaus to temporarily assume the post of OB:49 Dr Franz Xavier Stadelmayer, a pre-1933 OB of nearby Würzburg, a member of the Bavarian People's Party (BVP), parallel in Bavaria to the Catholic Center party $(Z)$. Stadelmayer had also become a member of the NSDAP, although not until 1944. Stadelmayer readily informed Keller of this; Keller made it clear he would only serve until a more suitable choice could be found. 50

47Niethammer, Entnazifizierung 142. The direct responsibility for denazification would eventually be handed over to the Germans -- to the relief of overworked MG officers; special denazification courts (Spruchkammer) were set up to handle the multitude of cases.

${ }^{48}$ Chronik 43.

49 Wagner 156.

50 Boehling 359. Keller was impressed with Stadelmayer's administrative capabilities and knowledge of Munich conditions, and kept him on as Deputy Oberbürgermeister, or 2. Bürgermeister (Boehling 359). 
This first choice for OB, Karl Scharnagl, was found soon thereafter and appointed OB on May 4.51 Scharnagl was a former Munich OB and BVP member. Scharnagl, a baker by trade, had done time in Dachau, and because he feared last-minute retaliations spent the last weeks of the war in hiding. Scharnagl at first hesitated at Keller's request but Keller told him he would be well-assisted and supported by MG; in any case he could also force Scharnagl to take the post. 52

Many ministers appointed by MG or Scharnagl (with MG's blessing) were connected to the BVP and the Catholic Church. Unofficial MG advisor Cardinal Faulhaber definitely favored such appointments. Since a young age OB Scharnagl, for example, had been very active in Catholic groups. Furthermore, Scharnagl's brother was a bishop under the cardinal's jurisdiction. 53

Many of the officials reinstated were of conservative, pre-1933 orientation. Not all were affiliated with the Nazi party, but many were, and soon found themselves dismissed because of MG adherence to denazification directives. In Munich, careful denazification was practiced from the start. Each city employee reporting for duty was required to fill out a Fragebogen, the MG questionnaire on an individual's past and involvement with the Nazi party or related organizations. The questionnaires were screened by MG's Special Branch, which was

$51_{\text {Chronik }} 43$.

52 Boehling 360; Wagner 157-158.

53 Boehling 361 . 
responsible for denazification. The head of Munich Special Branch, Captain Kurt Baer, was a German Jewish emigre who, unlike many specialized MG officers, was first concerned with denazification, and second with appointing efficient personnel. 54 The number of Fragebogen became so great, however, that many were personnel were allowed to work temporarily until processing of the questionnaires was finished. 55 This caused a minor gap in dismissals. Of the original 15 acting department heads appointed by OB Scharnagl, nine had to be removed by MG before the end of May. 56

Despite the tendency to search out pre-1933 officials, there was more reinstatement of concentration camp victims and political persecutees in Munich than in other large US Zone cities: "Overall . . . . Munich seemed to have had a more progressive and representative municipal administration in 1945-46 than either Frankfurt or Stuttgart." 57 In the first months Munich MG appeared to establish a natural balance between specific, pragmatic concerns and broader goals of denazification and political reform.

${ }^{54}$ Boehling 360.

55 Boehling 376.

56 Boehling 375 .

57Boehling 377-378. 
THE FLEETING ROLE OF THE FREIHEITS-AKTION BAYERN

In the days before and after the capitulation the Freiheits-Aktion Bayern (literally: "Freedom Operation Bavaria") was able to create much confusion among remaining German defenders, aid the efforts of tactical troops, assist the CIC and facilitate the establishment of MG.

Nevertheless, such groups claiming to be "Anti-Nazi" presented MG with a challenge. According to directives CSS 551 and JCS 1067, the "worst" Nazis -- high party members, SS men -- were to be expelled and in many cases imprisoned. How were groups of an "opposite" stance -- which MG did not expect -- to be controlled? The example below illustrates the limits in allowing Germans a role.

The efforts of the Freiheits-Aktion Bayern (FAB) helped assure that US troops could take Munich without much resistance. 58 In the night of April 27-28, 1945, an assorted group of civilian and military men attempted a goal they had coveted since Hitler came to power, with plans they had formulated for over a year: revolt throughout Southern Bavaria. Before the uprising began the FAB managed to channel a US and a French prisoner of war through Allied lines to inform Allied commanders of the impending rebellion, and to appeal for a stop to air bombardments. Further heavy bombings were canceled for this reason. 59

The core of the FAB came from a Wehrmacht interpreter unit, Dolmetscherkompanie VII. Captain Dr Gerngroß, Major Caracciola and

58 Bayerische Landeszeitung. Nachrichtenblatt der Allierten 12. Heeresgruppe für die deutsche Zivilbevölkerung June 1, 1945, 1.

59 Boehling 357. 
Major Braun from this unit led the $F A B$ revolt. 60 In a statement of vague goals 61 the $F A B$ hoped for a union of all Nazi opposition. Indeed, for the revolt itself the FAB cooperated with the socialist group "07"62 as well as the monarchist group "Bayerische Freiheitsbewegung." The FAB and fellow groups rose up with varied success and failure around Munich and in most Landkreisen in Southern Bavaria. 63 The FAB was reported very active in Miesbach, for example. 64

The FAB was able to create an amount of chaos among remaining German forces, and for about twelve hours assumed official powers. In the early morning hours, with support from a batallion belonging to the 17th Panzerdivision, the FAB captured the main broadcasting stations in Erding and Freimann on the outskirts of Munich. From there they broadcasted the signal for the revolt to begin, 65 and members of the interpreter unit called upon foreign forced labor to "rise against the Nazis." Factory workers blocked some access roads to Munich from which SS reinforcements were expected. Railroad men brought trains to a halt.

60 Chronik $41-42$.

61 The FAB agenda in: Franz Obermaier, Josef Mauerer, Aus Trümmern wächst das Neue Leben (Munich: Neue Münchner VerlagsGmbh, 1949) 9ff.

62 Boehling 357.

63Niethammer, Entnazifizierung 126-127.

64 BayHStA OMGB(Y) 13/142-1/7, MG Weekly, May 13-20, 1945.

65: The signal was Fasanenjagd, or "pheasant hunt" -- wartime slang for the high-ranking Nazis was "pheasants." 
FAB managed to capture and for a short time occupy some key party and municipal offices, including the Rathaus and the building housing the Nazi paper Völkischer Beobachter. 66

FAB members searched out important local Nazis. In the Rathaus they took prisoner the powerful Parteigenosse, Ratsherr and Kreistagspräsident 67 Christian Weber. Nevertheless, many targeted figures were not located. Significantly, Gauleiter Giesler was not present in his headquarters. He had fled Munich 68 after entreating public officials to stay at their posts and threatening them with harsh punishment if they did not. Moreover, the leaders of the FAB failed to convince the leading Munich-area Nazi Reichstatthalter Ritter von Epp to begin immediate surrender negotiations with the Allies. 69

${ }^{66}$ Bay. Landeszeitung June 1, 1945, 1.

67 Parteigenosse = Party Member; Ratsherr = Councilman; Kreistagspräsident $=$ District Assembly President.

68 Boehling 357.

${ }^{69}$ Chronik 42 . "Reichstatthalter" was a powerful position in the NSDAP of ambiguous and almost untranslatable meaning, commonly reserved for "Alte Kämpfer" (Old Fighters) such as von Epp.

Reichstatthalter, created in 1933, represented the central Reich Government (Reichsregierung) within the lands of the Greater German Reich (Deutsches Reich). The Reichstatthalter reported to the Reich Interior Ministry, had the duty of making sure that the Führer's policies were correctly followed, and suggested proper candidates for the Führer to appoint to the Land Governments (NS-Deutsch. "Selbstverständliche" Begriffe und Schlagwörter aus der Zeit der Nationalsozialismus, ed. KarlHeinz Brackmann and Renate Birkenmeier [Straelen: Straelener Manuskripte Verlag, 1988, 159]). (An MG report translates Reichstatthalter as "Land Director" (BayHStA OMGB[Y] 10/85-3/5, Weekly Military Government Report for Land Bavaria [hereafter: MGB Weeklyl, May 21, 1945.), ironically the later, milder MG term for the commanding US Land governor. 
Meanwhile, SS units were able to penetrate into the city. By the late afternoon of April 28 bloody skirmishes had ensued between FAB men and the SS troops. The FAB was not able to hold its positions. By 5:00 p.m. on April 28 it was announced the revolt had been suppressed. Carriaccola was caught, immediately subjected to a court-martial, and executed. Other FAB leaders, including Dr Gerngroß, survived. 70

The uprising revealed to MG that resistance did exist within Germany, yet MG and tactical troops had been instructed to make no distinction between common Germans and Nazis. The non-fraternization directive discouraged possible "collaboration." Moreover, in this early stage the only clear guidelines MG detachments had on appointing personnel were negative ones: no "Nazis, Nazi sympathizers and militarists" were to be given administrative positions. 71

Initially, impressed $M G$ and tactical officers allowed the $F A B$ a significant role. In many outlying areas immediately before or after US troops entered, FAB or related activists installed themselves in top administrative posts, and the first US troops to arrive did not object. 72 In Munich, General Harris of the CIC arrived and approached FAB leaders to offer them the chance to cooperate. Harris, who represented only the CIC, explained that general Munich MG goals were not his concern and used FAB men in finding and holding "dangerous" Nazis.

70 Chronik 41-42; Bay. Landeszeitung June 1, 1945, 1.

71 Boehling 341 .

72 Wagner 144. 
FAB men were given an office and were required to issue reports to the CIC, a task the FAB fulfilled zealously. 73

In a very short time the $F A B$ seemed to become pivotal. It was suddenly attractive, and within days the FAB ranks grew rapidly. The office became overwhelmed with the task of registering and employing new members, and was a meeting place for deliberations among members of varied political orientation. The FAB post became an "unofficial Rathaus;" MG and CIC initially allowed political discussion within the FAB ranks, although political organization of any kind was officially strictly forbidden. ${ }^{74}$ Munich MG approached the FAB for advice on suitable personalities for administrative posts. 75

Nevertheless, the FAB's purpose was dubious, its function shortlived. It became clear that too many questionable characters and opportunists were flooding into the FAB offices. Munich FAB leaders had hoped to coordinate plans with groups which were quickly gathering strength and responsibilities in the rest of Southern Bavaria. Munich FAB leaders wanted to avoid any confusion of interests. The breakdown of communications, however, gave the Munich office little if no control over FAB activities outside of Munich. 76 MG, abiding by its own

73Wagner 155: Concerns over Nazi-guerrillas, above all the "werewolves," influenced many early decisions involving military security.

${ }^{74}$ Niethammer, Entnazifizierung 129. According to the directives CSS 551 (Holborn 138) and JCS 1067 (Holborn 162), political association or activity was forbidden, unless MG "deemed otherwise."

75Wagner 156; 164-165.

76 Wagner 165. 
directives, did not allow telephone or messenger contact between the FAB headquarters and groups outside of Munich. MG became angered by actions it saw as opportunistic. FAB took it upon itself to distribute member identification cards implying official MG authorization, allow members to carry weapons, and assume entitlements of officials. 77

In this early stage of the occupation, such rapid developments proved too hazardous for MG. It appears that MG simply did not trust an "anti-Nazi" organization so suddenly popular. The FAB was by far the most powerful of the three prominent movements, and MG considered such a group a clear refuge for opportunists with a past: "[the FAB] . . . offers an admirable mechanism for infiltration by former NSDAP members either wishing to whitewash themswelves or to facilitate their accomplishment of whatever long-term mission they might have been assigned."78

MG's empowerment of the FAB lasted only two weeks. On May 15, two CIC officers came to the FAB leaders, voiced harsh accusations and made it clear that the FAB's influence must be diminished. Two days later the officers returned to declare that, according to occupation directives organizations like the FAB had to cease operation. CIC men requisitioned the FAB files and closed the office. 79 Regional MG of Bavaria ordered that all FAB officials everywhere had to stop activities

77 Niethammer, Entnazifizierung 130-131.

78 BayHStA OMGB(Y) 10/85-3/5, MGB Weekly, May 21, 1945, 6.

79Wagner 165; Niethammer, Entnazifizierung 131. 
immediately. 80 Regional MG considered the following the most prominent "unsanctioned activities" of the FAB: 81

(1) Representation of itself as the sole organization sponsored by and sanctioned by Allied authorities, and as the sole and most effective channel of approach to American Military Government.

(2) Granting by Gerngross to members of, or supporters of, his organization of laisser-passer allowing travel, relaxation of curfew restriction or firearms permits, without the concurrence of or reference to AMG. Those permits were issued on the letterhead of the FAB and signed by, or for, Gerngross.

(3) Unauthorized requisition by members of the FAB of vehicles and buildings on their authority alone, representing themselves as supported in their actions by U.S. authorities.

Whatever the official reasons, explanations and accusations regarding FAB exclusion abound. Rebecca Boehling (358) suggests that the FAB leaders' own decision to distance themselves from the CIC might have contributed to the ban. Interestingly, the influential Cardinal Faulhaber presumably played a role in the FAB's demise: the cardinal not only disliked FAB leader Dr Gerngroß -- because he was Protestant and married to a non-Bavarian -- but very likely "decreased MG's confidence in the FAB." 82 At the same time -- curiously -- Cardinal Faulhaber, in a patriotic appeal, advised another FAB leader (and Protestant), Dr Ottoheinrich Leiling, not to work too closely with the Americans. 83

80 BayHStA OMGB(Y) 10/85-3/5, MGB Weekly, May 28, 1945, 9.

${ }^{81}$ BayHStA OMGB(Y) 10/85-3/5, MGB Weekly, May 21, 1945, 6.

82 Boehling 361.

${ }^{83}$ Boehling 361 . 
By the end of May MG clarified the limits of local German initiative. On May 25 Munich MG announced that political parties, organisations, groups or anti-Nazi groups and organizations were not allowed to organize themselves, set up offices or hold gatherings of any kind. Furthermore, they were not empowered to confiscate vehicles, provisions or buildings. The distribution of posters, books, leaflets, and other printed materials was forbidden. Any activities had to cease immediately. 84 Many Germans reportedly welcomed the move. Regional MG found the population "well satisfled" with Munich MG's decision to abolish all political organization: it was becoming "common knowledge that the FAB was a non-reputable group whose leaders wanted to establish themselves with Allied authorities to further their own opportunistic ambitions." Meanwhile, some FAB members themselves reportedly admitted that their organization was "getting out of hand." 85

In a presumably sudden understanding of what was to come, many in the FAB simply disappeared from the scene. The FAB and associated groups faded fast, the many questionable members even faster. On the outskirts of Munich and in the Southern Bavarian Landkreisen the situation was the same. This summary of the FAB illustrates a common fate: 86

In both the Miesbach and the Bad Aibling area the Freiheits Aktion Bayern was extremely active in the early days. During the Nazi

${ }^{84}$ Chronik 54.

85BayHStA OMGB(Y) 10/85-3/5, MGB Weekly, May 28, 1945, 9. 86 BayHStA OMGB(Y) 10/77-3/1 AHR Miesbach 2. 
regime a few men formed the core. Its inspiration was historic Bavarian separatism and there does not seem to be in this area at least, any record of active opposition among these men to the NSDAP. In the last days of combat hundreds suddenly became F.A.B. [sic]: those who might have originally formed a real resistance movement were lost in the crowds of those climbing on a new band-wagon. Many saw in the German defeat hope for an independent Bavaria, many others hoped to hide their activity or lack of it, under the F.A.B. banner. Until the quality of members of the F.A.B. and their political aims became evident, the party had some influence and through Military Government officers, placed men in fairly important positions. As the true nature of the movement became clear, those who had nothing more then their F.A.B. association to recommend them, were replaced. Generally the great majority of F.A.B. was absorbed into the CSU.

Regardless of internal problems, the somewhat dubious FAB was destined for a fleeting role. After all, MG directives forbade any political organization or cooperation. The cautious, strict Munich MG was much more evident than the lenient one.

At the early stage of the occupation, MG preferred "indirect rule" but restrained German "ambitions." Discipline, not democratization was the goal. The preceding examples reveal how inconsistent this practice could be in the first months of the occupation.

Although not without flaws, the effectual and well-trained Munich detachment provides a clear example of proper, capable Military Government. The Miesbach detachment, however, failed in some important areas. Still, it is difficult to fault the Miesbach MG officers given the impossible conditions and immense hurdles. For German groups like the $\mathrm{FAB}$, the fate was even more direct and damning. 


\section{CHAPTER IV}

\section{DEFINING AUTHORITY AND ASSURING PUBLIC SAFETY}

The German defeat of May 1945 ended 12 years of a system that expressed itself most directly by strictly enforcing order and exercising complete control, or at least the widespread perception of it. US occupiers found it suddenly necessary to fill the immense void of contrived order by means as uncompromising and martial. Ambitious US aims required from the beginning the strictest information control and public safety policies for the goals to succeed at all. As any conquering occupation force must do, American occupiers were obligated to rule absolutely.

As obligated ruler, MG held the prominent responsibility "to maintain and preserve law and order; and . . . to restore normal conditions among the civilian population as soon as possible." 1 To maintain this law and order, or "public safety," MG was forced to assure a secure environment for local civilians while at the same time strictly controlling them. ${ }^{2}$ To eventually "allow" Germans to develop a fresh perception of order according to democratic ideals and eventually nurture

\section{lFrom CSS 551 in Holborn 137.}

2 Some issues relevant to law and order -. military security, intelligence, or political investigation, for example -- are worthy of a whole study themselves, and are not stressed in these pages. 
from this void a rejuvenated system, the US occupier's form of control would have to gradually assume a very different manner from those the of Nazi past. The example of MG reestablishment of the Munich and Bavarian police illustrates the challenges presented by creating and guiding a new, untainted authority from the infamous old.

According to the considerations above, this chapter explores first how MG clarified policy and assured a secure environment through strict measures and the "direction" of information, and second the reactivation and control of German police authority.

\section{CLARIFYING THE NEW ORDER}

Germany was a conquered enemy. Yet for MG to achieve the initial task of "getting things going again," a -- relatively -- stable atmosphere had to be established. MG, stated CSS 551, "Shall be firm. . . . [but] will at the same time be just and humane with the respect to the civilian population." 3 JCS 1067 nevertheless made it clear that circumstances were not yet ripe for many freedoms: 4

Germany will not be occupied for the purpose of liberation but as a defeated enemy nation. Your aim is not oppression but to occupy Germany for the purpose of realizing certain important Allied objectives.

Directly upon arrival, MG instituted a series of strict controls and measures that clariffed this new relationship. Reasons were two-fold:

3Holborn 136.

4JCS 1067 in Holborn 159. 
cautious military security and political requirements ("all Germans are Nazis") determined one. The need for law and order determined the other, and was presumably welcomed by German clvilians. In the first months and after, there were many threats to public safety: plundering and widespread theft; murdering "robber bands;" and angry, revengeful forced laborers.

The rigid new order under MG was initially and not unexpectedly quite restrictive, yet loosened even after the first months. The strict antifraternization law, for instance, was meant to assure distance between occupler and occupied Germans. It soon became clear that not all Germans were dangerous or Nazis, and the controversial ban was gradually toned down. 5 Speaking in public with Germans was allowed by July 21,6 but was only "officially" lifted in the fall of 1945.7

The many occupation laws and proclamations are far too numerous to list. The following brief rundown of immediate MG measures in Munich lllustrates the environment. Civilians -- of any nationality -- were kept inside by curfew from 7:00 p.m. to 6:00 a.m. Those found outside could expect a prison sentence. Evacuated persons

5 For reasons behind the indecisiveness regarding nonfraternization policy, see Ziemke, Army 32 1-7.

${ }^{6}$ Chronik 64.

${ }^{7}$ Münchner Zeitung. Alliertes Nachrichtenblatt (hereafter Münchner), Sept. 22, 1945, 3. Of course, American GIs and Germans did speak to each other, regardless of regulations. In any case, neither marriages between American soldiers and German women nor the living of soldiers in German homes was yet allowed (Mü. Zeitung, Sept. 29 $1945,2$. 
were not allowed to return to Munich, and those inside Munich were not allowed to leave, until further notice. Many main streets in the inner city remained closed and off limits, primarily to secure passage for military vehicles. Any vehicle found in these streets was immediately confiscated. Plunderers were warned of the strictest sentencing. The theft or possession of US military property was highly forbidden, regardless of the source. ${ }^{8}$ Correspondence or communications of any kind, even by messenger, were strictly forbidden. ${ }^{9}$ Nevertheless, the new regulations also meant the end of old ones. On May 1 the black-out regulations in effect since Sept. 3, 1939 -- lasting 2077 nights -- were lifted. 10

It is important to consider briefly how MG communicated policy, established its influence, and secured the environment. The Public Safety Branch of MG considered one of its major achievements "the formulation and execution of policy for the establishment and maintenance of law and order." 11 This task was naturally crucial, yet the news of significant MG policies had to readily reach the occupied.

During the combat period, the Psychological Warfare Division of SHAEF (PWD/SHAEF) exercised the responsibility for "information

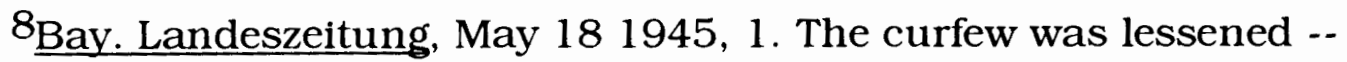
gradually -- over the following months.

9Wagner 154. Most communication had already been disrupted; postal services, for example, had stopped almost two weeks before the first American troops arrived (Wagner 154).

${ }^{10}$ Chronik 51.

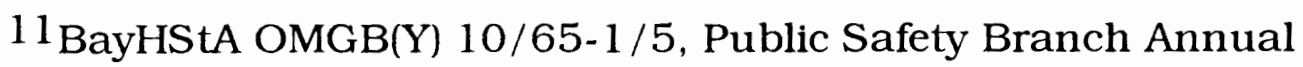
Report (hereafter PSBAR), June 1946, 1. 
control." The Information Control Division (ICD/USFET) replaced PWD with the disbandment of SHAEF in July, but without any noticeable change in policy. 12 Press policy was clearly formulated and implemented. It involved three phases: 1) the ban of all German media; 2) the establishment of Allied information services and -- corresponding to denazification and democratization -- an exact scrutiny of the German media; and 3) the gradual transfer of media operations to Germans, but under Allied controls. The short term policy goal was military, the long term political. 13

How was the widespread clarification of MG accomplished, and law and order furthered, under the chaotic circumstances? In the initial occupation, the first two phases mentioned above were obvious. German media remained banned, and MG's ICD informed the occupied of the many proclamations and laws. As the American armies moved farther into Germany, the Publishing Operations Branch of the ICD distributed Mitteilungen ("Bulletins") for the German population. The main purpose of these were to: 1) make public all laws, proclamations, orders, and

12 Elisabeth Matz, Die Zeitungen der US-Armee für die deutsche Bevölkerung (1944-46) (Münster: Verlag C. J. Fahle, 1969) 47. On Allied propaganda and press policy: Deutsche Presse seit 1945, ed. Harry Pross, (Bern: Scherz, 1965); Norbert Frei, Amerikanische Lizenzpolitik und deutsche Presse-tradition. Die Geschichte der Nachkriegszeitung Südostkurier (Munich: Oldenbourg, 1986); Hans Habe, Im Jahre Null: Ein Beitrag zur Geschichte der deutschen Presse (Munich: Verlag Kurt Desch, 1966); Harold Hurwitz, Die Stunde Null der deutschen Presse. Die amerikanische Pressepolitik in Deutschland 1945-49 (Cologne: [publisher $\mathrm{n} / \mathrm{a}], 1972$ ); Larry Hartenian, "The Role of Media in Democratizing Germany: United States Occupation Policy 1945-49," Central European History, 20.2 (1987): 145-190.

13Matz 20-21. 
other important information; 2) provide reports in local areas on how daily life should continue under MG; and 3) "stabilize" conditions, by curbing rumors through the release of exact information. 14

By the end of hostilities a more thorough brand of "newspaper" was developed, published by a central editorial staff, and provided to the German population. These combined official announcements with local sections, commentary, and world news. Nevertheless, the layout remained sparse, the approach stern. Despite objections from the editorial staff, an "engaging" character was to be avoided. 15 It was too soon for this. General McClure, commander of ICD, made it clear that "It is PWD's policy not to entertain Germans." Moreover, he clarified, the Germans do not need to form their own opinions, they "have to be told." 16

By the time US forces had reached Southern Bavaria, a more extensive form of occupation newspaper had been established, and allowed local MG to clarify its goals effectively. Munich had been without printed news since April 30, 1945, when the Münchner Neueste Nachrichten halted its operations. On May 18, MG published the first Bayerische Landeszeitung. It appeared only three times, reached a total circulation of 328,00 , and ended its run on June 1 . The Landeszeitung

14 Matz 31.

15Matz 37-41. New for German readers was the clear distinction between news and commentary indicative of American media. This style of objective reporting was adapted by the renewed postwar German press.

16 Matz 43-44. 
was followed by the Münchner Zeitung, which appeared weekly from June 9 until the end of September, and achieved a circulation of 600,000.17 The papers only appeared periodically, but contributed nevertheless to clearing up major information gaps and helped MG stabilize the local situation. In the section "Die Militärregierung glbt bekannt" ("Military Government announces"), for example, MG clarified policies, announced ordinances and regulations, and warned of punishments for threatening law and order.

Still, the MG newspapers could only reach so many. The shortage of paper made it difficult to facilitate increased newspaper circtulation. Other methods were also used. Munich MG printed and distributed posters stating regulations, prohibiting political organization, and so forth. By July, Munich's ICD officers were operating two sound trucks for official announcements, and by August had made them available to the Public Safety section "for cases of special emergency." 18

Another media form -- radio -- assisted MG greatly, but its significance has been mostly ignored. It is important to note that the number of functioning radios was incredibly high; in Bavaria there were at least a million. Apart from initial technical problems arising from

17Dagmar Wiedenhorn-Schnell, "Medien an der Longe: Deutsche Lizenzpresse in München 1945-49," Trümmerzeit in München. Kultur und Gesellschaft einer deutschen Großstadt im Aufbruch 1945-49, ed. Friedrich Prinz, (Munich: Beck, 1984) 252. The first postwar Germanowned newspaper in Munich, the Süddeutsche Zeitung, was licensed by MG on October 6, 1945.

18BayHStA OMGB(Y) 10/78-1/4, Munich AHR 97. 
devastation and plundering, broadcasting was the only official organ free from material and circulation hindrances in this period, 19 provided electrical power was available.

By May 11, the ICD section was able to begin broadcasting from the badly damaged station of the former "Reichsender München."20 MG broadcasters, calling themselves "Radio München," began the first broadcast by issuing proclamations: "Hier ist Radio München, ein Sender der Militärregierung. Einwohner Münchens! Die Militärregierung gibt bekannt, daß ..."21 At first the broadcasts ran only twice daily, 22 one and a half hours long, but soon increased after a more suitable studio was found. 23 Mayor Scharnagl was able to deliver a censored radio talk on May 12.24 Listeners found the Radio München schedule in the ICD newspapers.

19 ,Rüdiger Bolz, "Von Radio München zum Bayerischen Rundfunk," Trümmerzeit in München. Kultur und Gesellschaft einer deutschen Großstadt im Aufbruch 1945-49, ed. Friedrich Prinz, (Munich: Beck, 1984) 240.

20 BayHStA OMGB(Y) 10/78-1/4, Munich AHR 97. This was the same station from which in the last days the FAB proclaimed its revolt and, after SS troops had regained it, Gauleiter Giesler issued his last proclamation (Bölz 240).

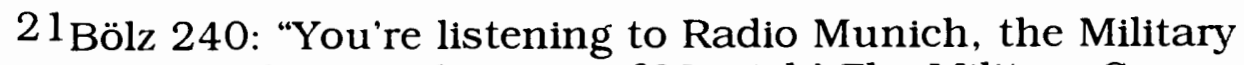
Government broadcaster. Citizens of Munich! The Military Government announces that ...."(translation by this author).

22 Chronik 50.

23Bölz 241.

${ }^{24}$ BayHStA OMGB(Y) 10/78-1/4, Munich AHR 97 


\section{REACTIVATING GERMAN POLICE AUTHORITY}

The examples of media, or "information control," illustrate how directly and comprehensively MG dominated German society. Such ardent and intensive practice of control had limits, however, even in police matters. In the early months of the occupation, military police and tactical troops were the ultimate guardians of law and order, 25 but could not patrol indefinitely.

The preference for indirect rule demanded that MG reestablish local German police as soon as possible, but under strict MG direction. The practical goal of MG's Public Safety Section -- establishing law and order -- was not, even in the initial stage, divorced from wider political goals. Public Safety staff were responsible for "the purging, reorganization, and reactivation of the German police agencies," as well as "supervision and control" of these agencies "in accordance with Military Government requirements." 26 Within a year MG had made significant strides towards these goals, but not without dilemmas. Developments in Munich during the first months of police reactivation illustrate the challenges and predicaments MG, and the German police, had to overcome.

25 As late as July of 1946 "all important incidents" were "reported instantaneously" to the Provost Marshall and to the Military Police Headquarters in Munich (BayHStA OMGB[Y] 10/78-1/4, Munich AHR $5)$.

26 BayHStA OMGB(Y) 10/65-1/5, PSBAR 1. For one of the few ample descriptions of police policy, see: Robert M. W. Kempner, "Police Administration," Governing 403-418. 
Allied planners considered certain German police bodies -- in the same manner as military and para-military organizations -- to be thoroughly "Nazified." According to the occupation directives, MG was to "seize and preserve all records and plans of the German military organizations and of the Nazi Party, and of the Security, Criminal, and Ordinary Police."27 The police agencies most directly under Nazi party control -- the Reich Criminal Police (Reichskriminalpolizei) and the Security Police (Sicherheitspolizei) -- were to be abolished. Not all police were to be disbanded initially. The standard criminal and ordinary police were only to be "purged of Nazi personnel and put to use under the control and supervision of the Military Government."28

MG was to reactivate "acceptable" German police immediately -- in the service of, and under the control of, MG. General Eisenhower, in a directive outlining and elucidating guidelines for police authority, decreed the following: "in general German local police carry the responsibility for maintenance of law and order, subordinate to MG control."29

Naturally, US troops and Military Police were available for support, especially in extreme conditions. Furthermore, army planners eventually developed the bold idea of maintaining an elite force of police-type

27From CSS 551 in Holborn 137. The same decree, with slightly different wording, is in JCS 1067 (Holborn 161).

28From JCS 1067, Holborn 163.

${ }^{29}$ Bay. Landeszeitung, May 25, 1945, 2 (translation from "Gründsätze im Polizeiwesen" by this author). 
occupation troops, the US Constabulary, to "assist German Civilian Police where necessary in controlling disorder caused by marauding bands of lawless individuals and to cooperate with German Police in the general maintenance of law and order."30 Despite enthusiasm, a lack of resources and troops kept the US Constabulary an impressive but relatively insignificant force. 31

Regardless, US forces could not expect to provide policing indefinitely. In Munich, for example, the Public Safety Section complained about the lack of US troops available for security purposes, a "security troop problem" Munich MG was watching very closely. By December 1945 less than 1000 US soldiers made up the "occupational security force." As a response, in the same month a security brigade of the Yugoslav Army was ordered to Munich, and companies of armed Polish soldiers carried out guard duty at certain installations. 32

As soon as capitulation appeared certain, Germans attempted to construct agencies for securing law and order. In areas in and near Munich, local Germans identifying themselves with the FAB or related anti-Nazi groups made themselves Bürgermeister and Police chiefs or were assigned the task by the local population. In most cases the first US

30 BayHStA OMGB(Y) 9/18-1/4, "Operational Procedure: US Constabulary, Military Government, and German Police Agencies, June 12, 1946" (hereafter Op. Procedure).

31Ziemke, Army 339-341; Davis 166-174.

32 BayHStA OMGB(Y) CO/445/1, Op. Report, Dec. 1945, 3: The Yugoslavian brigade consisted of five companies of roughly 10,000 "trained Army troops" of Yugoslavian nationality, directly commanded by their own General. 
troops did not object, 33 presumably appreciating the assistance. Few of these initial eager attempts lasted. Most of these hopefuls were soon dismissed by MG on account of unacceptable past activities. 34

In Munich on April 30 -- the day the first US units entered the city -- local "anti-Nazis" attempted to form a type of auxiliary police force. Members of the anti-Nazi group "07" (see chapter III) named one of their members, Willi Welßman, leader of a body they called the "Bayerische Hilfspolizel" (Bavarian Auxiliary Police). They began to recruit "policemen" and distribute identification cards. On the night of April 30 .. the night before the Munich MG detachment arrived -- Weißmann appeared at the Rathaus to request MG blessing for his operation. American troops there put him off until the next day, when he could then take up his proposal with more responsible authorities. Weißmann continued his operation nevertheless. In the printing room of the Völkischen Beobachter he and his men printed up leaflets warning against plundering and distributed them the next morning. 35

Munich MG's response to such initiative was swift and decisive. On the same morning, on May 1, Weißmann appeared again at the Rathaus. Recently arrived MG officers there had no time for Weißmann, and quickly put an end to the activities of the "Bayerische Hilfspolizei." MG forbade the leaflets and ordered Weißmann's force to disband. 36

33 Wagner 144

${ }^{34}$ BayHStA OMGB(Y) 10/78-1/4, Munich AHR 5. 35Wagner 144.

36 Wagner 148-49. 
Munich MG asserted direct control over the police situation. MG officers were at this time searching for their own man to head an official police force, under the direction of MG's Public Safety Section. 37 Demonstrating the "pragmatism" indicative of the early phase of the occupation, MG sought a competent, yet seemingly acceptable candidate active before 1933. On the afternoon of May 1, MG commander Kurtz's assistant Major Keller sent two of his officers to the Bogenhausen section of Munich in search of MG's first choice for Police Chief. The men had orders to locate the 71-year-old former Chief of the Bayerische Landespolizei (Bavarian State Police), Hans Ritter von Seisser. 38 Seisser had played a decisive role in the failure of the Beer Hall Putsch of November 9, 1923. Seisser, as head of the Munich police (Polizeipräsident), ordered the suppression of the revolt. 39

Seisser was brought to Major Keller, who asked him to take the office of Police Chief. Seisser accepted, then changed his mind. He claimed he would be too busy with his manufacturing business. Twentyfour hours later, Keller and Seisser met again. This time Keller demanded he take the post, and reminded him he could be forced to take it. Seisser

37 MG records unfortunately report little about the officers of the Munich Detachment Public Safety Section. A roster of the detachment for December 1945 (BayHStA OMGB(Y) CO/445/1, Op. Report, Dec. 19, $1945,7)$ lists four Public Safety Section officers: Maj. Frank C. Smith (date joined detachment $\mathrm{n} / \mathrm{a}$ ); Capt. Gerald Greene (joined detachment Aug. 16, 1945); Maj. Clarence A. Brown (joined detachment Apr. 14, 1945); and Capt. William G. O'Brien (joined detachment June 28, 1945).

38 Obermaier, and Mauerer 30.

39 Bay. Landeszeitung, May 25, 1945, 2. 
conceded, but under the condition that he recelve no salary or compensation. 40 On May 7 Seisser was officially named Police Chief. 41

Not surprisingly, the first days of police reestablishment in Munich were difficult. The demands of war had already ravaged the ranks of the Munich department: 263 officials lost their lives, and 52 were reported missing; 174 police reserves were killed, 97 reported missing, and 1,000 were in various prisoner-of-war camps in 1945.42 Upon the arrival of US troops, the Criminal Police were suspended. Uniformed patrolmen (Schutzpolizei -- literally: Protection Police) were either in custody or remained in their homes untouched. Policemen with much to hide had fled long ago to the country or beyond. Precincts and station houses were mostly closed up or abandoned. 43

The situation soon changed under Seisser and the Public Safety Section's direction. On May 7 Munich police personnel comprised only 100 patrolmen and 125 criminal police. Screening and "vetting" of personnel continued daily, yet at the same time concerted efforts were made to recruit new policemen. Remarkably, by the end of the month, MG reckoned the number of total police employees to have reached an amazing 3,700.44 Seisser appeared to receive full MG support, and

40 Obermaier, and Mauerer 30-31. The reasons for this request are unclear, but were presumably altruistic.

41 BayHStA OMGB(Y) 10/78-1/4, Munich AHR 44.

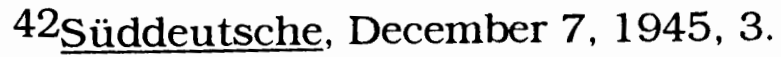

43 Obermaier, and Mauerer 31.

44 BayHStA OMGB(Y) 10/78-1/4, Munich AHR 44. 
cooperation seemed successful. Every morning meetings between Public Safety Branch officers and Munich police were held to discuss the events of the last 24 hours, as well as future measures. 45

Despite this apparent rebirth of the Munich police, the situation soon changed. Finding "acceptable" police personnel became the most significant problem. As mentioned, MG efforts to reestablish local German administration were marked by dilemmas. MG was to initiate plans but dominate affairs as little as possible. Nevertheless, figures with a connection to the Nazi party had to be shut out, at first according to a combination of MG judgment and useful $\mathrm{CIC}$ intelligence information. The early emphasis on efficiency, especially before the July directive, caused various specialized sections of $M G$ to apply denazification irregularly. 46

The Munich MG Public Safety Section prematurely reported in late May that "the de-nazification of the present police force is approximately two-thirds over and proceeding as quickly as conditions permit." 47 In fact, the authentic purge was yet to come. With more thorough formulation of denazification policy, the recruitment of suitable personnel became even more problematic. With the MG directive of July 7,1945 , a clear-cut denazification policy was set in motion. Categories of

45 Obermaier, and Mauerer 55 . Seisser reportedly appreciated the proficiency of what he considered well trained and organized Public Safety officers (55).

46 Niethammer, Entnazifizierung 147-50.

47 BayHStA OMGB(Y)10/85-3/5, Weekly MG Munich, May 13-20, 1945. 
Germans to be denazified, and released from positions, were introduced. Included in the first category, those who were to receive mandatory dismissal, were all ordinary police officials from the top down to lieutenant, regardless of Nazi party membership. 48 Already before July, Munich MG began to apply a more strict and comprehensive denazification. On June $16 \mathrm{MG}$ announced that all municipal officials (Beamte), employees (Angestellte), and workers (Arbeiter) who had joined the Nazi party or associated organizations before January 30, 1933, would immediately lose their positions. 49

In June the police denazification was begun anew. MG Public Safety acted to suspend and purge the entire police department, with the goal of establishing "from the ground up an efficient and thoroughly denazified Police Department."50 A gap in Fragebogen processing -discussed in the previous chapter -- might partially explain why MG Public Safety waited as long as it did to act, and allowed the police department to expand in May. Regardless, MG reports for June cite a specific reason for prompting the action: extensive Nazi party membership records were discovered, 51 revealing that most of the police personnel were somehow affiliated to the Nazi party. 52 The entire

48Niethammer, Entnazifizierung 153.

${ }^{49}$ Chronik 58.

50 BayHStA OMGB(Y) 13/142-1/7, MG Weekly, June 3-10, 1945.

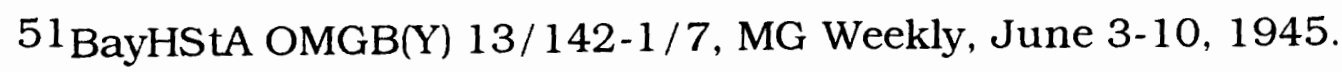

52 BayHStA OMGB(Y) CO/451/2, Op. Report, July 8, 1945, 29. 
department was officially suspended on June 5, 1945, and a minimal staff was kept on to take care of administrative tasks. 53

A few officials cleared by investigation were appointed to serve as the basis for a new force. 54 Police President Seisser was one of those few officials. He managed to last in his post until MG dismissed him in midAugust. The causes for this are not entirely clear. The only brief account of Seisser's dismissal states that, despite his role in the Beer Hall Putsch, MG discovered that in the last years of the Weimar Republic Seisser had gotten too close to the increasingly influential Nazi party. 55 In any case, an outside MG observer reported in July that although "not a Nazi [Seisser] is not aggressive and his removal is being considered." 56

Seisser might have lasted so long only because it took weeks of negotiations and consideration before the new candidate could be persuaded to take the police chief post. 57 As Seisser's successor MG appointed a more satisfactory choice; one with no conceivable connection to the Nazi party: Franz Xavier Pitzer, 58, a Catholic, and SPD member from 1903 until 1933. Pitzer was a trained craftsman and carpenter, and a union member. In 1918-19 he organized the Bavarian

53BayHStA OMGB(Y) 13/142-1/7, MG Weekly, June 3-10, 1945.

54 BayHStA OMGB(Y) 10/78-1/4, Munich AHR 45.

55 Boehling 376. Curiously, the pages in Chronik $(47,50)$ Boehling quoted for this information deal with events of May -- Seisser's appointment, for example -- and include no mention of Seisser's dismissal whatsoever.

56 BayHStA OMGB(Y) CO/451/2, Op. Report, July 8, 1945, 29.

57 It is unclear whether Seisser knew of these developments. 
Military Police and served as assistant police chief (Vizepräsident) under the Independent Socialist Staimer. Thereafter, Pitzer decided to quit rather than serve under the reactionary Police President Pöhner. He withdrew to civilian life after 1919.58

Pitzer assumed the post on Aug. 16, 1945.59 It appears MG wanted to show off the new appointment -- and department -- to its Münchner. In a notable piece of "information control," a long, flattering article in the sober MG Münchner Zeitung introduced Pitzer. Pitzer's first quoted comments were reported as follows: "The policeman comes from the people, and is there for the people; he must be the best friend of the people. $" 60$

MG's new man Pitzer seemed a more acceptable appointee, and lasted in his office for a good time. There is an ironic note to all this, however: later, in 1949, MG would advise then OB Wimmer to dismiss Pitzer. A MG report found the Munich police the worst organized and managed force in all of Bavaria, and blamed Pitzer for having not the slightest elementary understanding of police administration. 61

Furthermore, Pitzer .- known as a stalwart opponent of the burgeoning

58 Münchner, August 25, 1945, 3.

${ }^{59}$ Chronik 69.

60 Münchner, August 25, 1945, 3 (this author's translation): "Der Polizist kommt aus dem Volk, und er ist da für das Volk; er muß der beste Freund des Volkes sein."

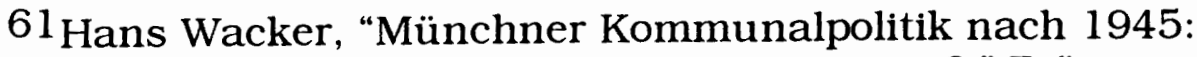
Nachlaßverwaltung oder demokratische Erneuerung?," Trümmerzeit in München. Kultur und Gesellschaft einer deutschen Großstadt im Aufbruch 1945-49, ed. Friedrich Prinz, (Munich: Beck, 1984) 56. 
black market -- was himself found to be involved in "illegal transactions." 62

Constant reorganization of the Munich police continued throughout 1945. In June it appeared the department was less of a factor in the maintenance of law and order than at the end of hostilities. As mentioned, on June 5 the entire department was suspended. On June 11 $M G$ officially ordered a department reorganization, and in the days thereafter the number of officials grew, but only slowly. On June 12,8 detectives (Kriminalpolizei) were on duty; by June 22 there were 22 . In normal times there were normally 300 detectives on duty in Munich.63 By June 20 police precincts recommenced operation, but only to a limited extent. 64

Reorganization did progress. At any rate, the ability of Munich policemen to act independent of MG was limited at this early stage. General Eisenhower's aforementioned directive decreed that German police were to be disarmed and remain that way; only for special emergency cases could certain groups be equipped with small arms and strictly limited ammunition. 65 Early on Police Chief Seisser had

62 Juliane Wetzel, '“Mir szeinen doh:' München und Umgebung als Zuflucht von Überlebenden des Holocaust 1945-48," Von Stalingrad zur Währungsreform: Zar Sozialgeschichte des Umbruchs in Deutschland, eds. Martin Brozsat, Klaus-Dietmar Henke and Hans Woller, (Munich: Oldenbourg, 1988) 356.

63Obermaier, and Mauerer 55.

${ }^{64}$ Chronik 59. Registration desks (Meldestellen) were only open 8 am - 12 pm Monday through Saturday (Münchner, June 23, 1945, 2).

$65_{\text {Bay. Landeszeitung, March 25, 1945, } 2 .}$ 
requested arms as well as uniforms for his men; he was told that arms were neither authorized nor available. 66 In this period the police carried only truncheons, which had little effect against armed plunderers and marauders. 67 Lack of proper equipment was naturally a constant problem. Under MG regulations, former uniforms had to be dyed and altered to avoid any resemblance to militaristic Nazi era uniforms. 68 Funding was an initial problem. Between May and June many officials went weeks without any pay. 69

Munich police remained under close MG guidance, and were only gradually, after proving themselves, given full responsibility to carry out their work. The following MG report excerpt illustrates this: 70

German police were detailed to foot traffic duty, working with Military Police. It was planned, that at such time as they were deemed fit to assume their independent duties without the aid of MP's they would be put on independent duty, and another group of civilian policemen would be detailed with the Military Police.

Certain matters remained under the jurisdiction of Military Police. The detention and imprisonment of Displaced Persons (DPs), for example, was forbidden to German police. The Allied Powers had declared DPs United Nations nationals. Whenever German Police arrested DPs, they

66 BayHStA OMGB(Y) 10/78-1/4, Munich AHR 44.

67 Wacker 55.

68 BayHStA OMGB(Y) 10/78-1/4, Munich AHR 44.

69 Obermaier, and Mauerer 55. MG eventually obtained police funds from the Staatsbank (55), but the funding troubles continued.

70 BayHStA OMGB(Y) 10/78-1/4, Munich AHR 47. 
were required to immediately turn them over to US authorities, provide arrest reports, and report the arrest to MG. 71

It was difficult to find men for the police at this stage because of their abject rewards and reputation, as well as the fact that a satisfactory Fragebogen was required. 72 Under these conditions the Public Safety section felt it necessary to start a recruiting drive, intensified by radio broadcasts and newspaper appeals. This appears to have contributed to somewhat rapid growth. By August the total number of employees had reached 1,039, broken down in the following groups; 711 patrolmen, 125 detectives, 170 administrators and 35 housekeeping personnel. 73

Reinstatements also contributed to the notable rise in personnel, but the buildup was inconsistent. During the first week of September, for example, " 28 men were discharged, 240 were reinstated and 280 applications for employment were rejected." MG managed to maintain police numbers by constant shuffling of police personnel from one capacity to another. 74 The following chart from MG documents illustrates police growth from August until October 1945:75

71 BayHStA OMGB(Y) 9/18-1/4, "Op. Procedure," June 12, 1946.

72Obermaier, and Mauerer 54.

73BayHStA OMGB(Y) 10/78-1/4, Munich AHR 47.

${ }^{74}$ BayHStA OMGB(Y) 10/78-1/4, Munich AHR 48.

75BayHStA OMGB(Y) 10/78-1/4, Munich AHR 51. 
Categories of Personnel:

Uniformed Police

Criminal Police

Administration

House Keeping [sic]

Total:
August 31 Sept 30

1,349

188

257

2

1,796
1,367

236

395

78

2,076
Oct 31

1,270

271

419

87

By December 1945 reorganization and purging resulted in the following totals: 172 administrative officials , 155 criminal police and 421 patrolmen had been dismissed. New appointments included 122 administrative officials, 75 criminal police, and 555 patrolmen. Almost without exception the new appointments were native Bavarians, from all walks of life. 76 Personnel instability certainly did not end in 1945. Many future aspirants proved "unacceptable" because of their pasts, and others unsuitable for police work.

Meanwhile, other problems of police reorganization were being slowly, partially resolved. Arming of the police was permitted in the fall. In negotiations with MG, municipal authorities made a concerted effort to convince MG of the necessity for arms. 77 This contributed to MG's decision, but the Public Safety Branch was reaching the same conclusion on its own. An August 1945 report determined that the "arming of the police remained the major problem .... unarmed men cannot be expected to rest behind the protection of a uniform or police card."78

76 S̈üddeutsche, December 7, 1945, 3.

77 Wacker 55.

78BayHStA OMGB(Y) 10/78-1/4, Munich AHR 48. 
By January 1946, Munich MG considered its initial rebuilding of the Munich Police Department largely over. There were still many problems to be solved -- reports indicate a lack of sufficient funding, for example. 79 Still, MG Public Safety proudly judged its efforts successful. The following MG report passage summarizes Munich MG's assessments: 80

The Munich Police Department had almost completed its reorganization and was considered to be one of the finest in the American Zone. The Uniformed Police are completely dressed in the new uniform of Royal Blue and Black trimmed with Silver Grey, and are equipped with breast shields of American design. The Police are armed with carbines and pistols of Italian make. There were, as of yet, not enough weapons to arm all the Police individually. Another handicap was the lack of sufficient vehicles in good condition to establish road patrols. At this time no motor patrols were in action. Telephone and teletype remained the principal means of communication. Radio transmitter was available, however, Radios for police cars had been requested but, as yet no action had been taken in this matter.

In December 1945 an outside MG observer judged the situation not as favorably: 81

. . . [the Munich police force], as now constituted, consists of 2,200 men and their efficiency is believed to be rapidly improving due to the continuous training on the job and the selection of most efficient personnel. It is reported that they need additional supply of small arms. Also, the Det has been unable to secure sufficient uniforms due to hold-up of material by the freeze at

79 BayHStA OMGB(Y) 10/78-1/4, Munich AHR 51.

80BayHStA OMGB(Y) 10/78-1/4, Munich AHR 52. In an effort to avoid militaristic connotation, the uniforms were designed after the American example: the tunics had a much looser cut, rank was displayed on the arms instead of on the shoulders, and the peaked cap introduced (Münchner, July 28, 1945, 2).

81 BayHStA OMGB(Y) CO/445/1, Op. Report, Dec. 19, 1945, 2. 
Third Army Hq. They report the Police Force has only 319 uniforms out of 1,410 required. They also require 1,100 overcoats.

Moreover, Munich MG reported to this source that "The efforts of the Det [sic] are practically exhausted to obtain supplies for local police." 82 The attention to equipment concerns reveal how MG was burdened with many problems in addition to the demands of carrying out denazification directives.

It would take much more than American-style police blues or police car radios to turn the German police into a capable force. Still, by the spring of $1946 \mathrm{MG}$ already considered many of its direct goals largely fulftlled. MG began to "advise," instead of "direct," a German police force gradually more independent of MG. The new German police would not operate under the sort of structure -- and jurisdiction -- it had before or during the Third Reich. A broader occupation goal was in play at this time, a product of the wish for not only a denazified but also a democratized Germany reformed "from the ground up." A series of directives stated how this applied to police reconstruction. General Eisenhower's guidelines for police authority emphasized that the police force was to be decentralized and rebuilt regionally and locally, as a component of local laws and administration. 83 A significant MG directive of July 7,1945 further formulated this line as well as the decrees of CSS 551 and JCS 1067. Organizational guidelines for the police were essentially finalized in MG regulations of February 1, 1946.84

82 BayHStA OMGB(Y) CO/445/1, Op. Report, Dec. 19, 1945, 2.

${ }^{83}$ Bay. Landeszeitung, May 25, 1945, 2. 
Before 1933, German police agencies had been largely subordinate only to each state's Interior Ministry (Innenministerium). During the Third Reich the police became more and more centralized under Gleichschaltung, the practice of forcing or bringing all agencies in line under Nazi party authority. In Bavaria, this process began in 1935 when the Landpolizei (Provincial, or State Police; responsible for the state of Bavaria as a whole) was made subordinate to the Reich. Since 1933 preparations had been made to incorporate the Landpolizet into the Reichswehr (the German Army from 1921-1935). The Criminal Investigations Police (Kriminalpolizei) and the Border Police (Grenzpolizet) were also centralized. In 1936 all police authority was made the responsibility of the Reich Interior Ministry. Rural police remained, but in practice were highly controlled by the consolidated police agencies 85

Decentralization under MG intended to create an organizational structure of police authority modeled on the American and English example. Jurisdiction and local responsibility were to be clearly defined. The goal was to create a situation whereby, as the Public Safety Branch described, "The police are subject to the will of the people instead of being used to enforce the will of the state upon the people." 86

${ }^{84}$ Handbuch der bayerischen Ämter, Gemeinden und Gerichte 1799-1980, ed. Wilhelm Volkert, (Munich: C.H. Beck'sche Verlagsbuch handlung, 1983) 54: The directive's title was "Administration of Military Government in the US Zone" (see also chapter II).

85 Handbuch 53; Kempner, Governing 403-406.

86 BayHStA OMGB(Y) 10/65-1/5, PSBAR 1. Due to largely political and financial constraints, the German police gradually became more centralized than originally planned (Kempner, Governing 411-418). 
Municipal police were put under the authority of the Mayor (Oberbürgermeister). He was required to establish a unified city police force which was headed by a chief of police and functioned within the city as a unit of municipal administration. Each mayor had the total administrative responsibility for the municipal police and exercised full control over property, facilities, and suitable personnel. 87

In Munich this new structure was novel. Since 1898 Munich municipal police headquarters (Polizeidirektion or Polizeipräsidium) was under Bavarian state control. 88 As part of its reorganization plans, Munich MG ordered the police to be integrated back into the municipal administration. Incidentally, the City Council (Stadtrat) gratefully received this chance to control municipal police authority. In the Weimar period, the city had felt it had to contribute too much to state police funding; at the same time it was constantly unsatisfied with municipal police performance and procedure. 89

Cities of less than five thousand citizens were permitted to organize a police department. These local community police (Gemeindepolizei) were under the command of either the local civilian councilor (Gemeinderat) or mayor. If a department was not created, the local civilian governmental head could arrange with the Minister of the Interior for policing. from the ranks of the Landpolizei. If created, this

87BayHStA OMGB(Y) 10/65-1/5, PSBAR 2.

$88_{\text {Handbuch }} 51$. Between 1923 and 1929 many large Bavarian cities adopted this example.

89 Wacker 55. 
form of police force was to have full authority throughout the county (Landkreis) in which they resided. In actual practice they would not go out of the city or community in which they were located unless they received a special request from the Landpolizei. 90

On the state (Land) level, MG reorganized the Landpolizet so that there was a Landpolizei headquarters in each Landkreis. The Landpolizei were allowed full jurisdiction throughout the state in which they operated. The Landpolizet were to assist the city police only in special cases; when requested to do so by the chief civilian governmental authority or by the Minister of the Interior. 91 Correspondingly, MG ordered that the Landpolizei be under the command of the Ministry of the Interior. 92

At the end of July 1945, MG named Michael Freiherr von Godin as the first head of the Landpolizei. Interestingly, Godin also had a decisive part in foiling the 1923 Beer Hall Putsch. Godin, then a police lieutenant, was at the head of a group of initially only 33 policemen facing 2,000 armed Nazi putschists. 93 When Hitler came into power the Gestapo put a death sentence on Godin. He was forced to flee to Switzerland where he continued to actively oppose the Nazi regime. MG called him back from Switzerland to take the post. 94

90 BayHStA OMGB(Y) 10/65-1/5, PSBAR 2; Handbuch 55.

${ }^{91}$ BayHStA OMGB(Y) 10/65-1/5, PSBAR 2.

92 $\underline{\text { Handbuch }} 56$.

${ }^{93}$ Chronik 66. 
MG stressed the reestablishment of Border Police. Initially, Border Police were to cooperate with US tactical troops in controlling the international boundaries of Germany. During the period from October 1945 to February 1946 a foundation for this organization was created, and MG instructed the Minister President of Bavaria to give "special attention and high priority" to the organization of the Border authorities. 95 The November 15, 1945 ordinance of the Bavarian Ministry of the Interior reestablished the Border Police as an official component of the Ministry of the Interior. 96 MG hoped to involve German authorities as soon as possible in the efforts to solidify the long Bavarian borders of the US Zone of occupation.

By the fall of 1945, US MG exercised complete control of the German population. MG strictly manipulated the media and police authority, two fundamentals of assuring law and order. That turned out to be the easy part under the circumstances. The hard part would come as MG attempted to guide Germans towards asserting a degree of local law and order themselves. As the next chapter reveals, challenging and peculiar crime problems severely complicated this process for MG and German authorities alike.

94 Münchner, July 28, 1945, 2.

95BayHStA OMGB(Y) 10/65-1/5, PSBAR 3.

$96 \underline{\text { Handbuch }} 57$. 


\section{CHAPTER V}

\section{LAW AND ORDER ISSUES}

In the early period of the occupation, "political" law and order among Germans was secured. The dreaded "werewolves" and other forms of resistance or anarchy never posed a clear threat. MG for Bavaria satisfactorily reported in July 1945 that the German population in the American Zone was generally orderly and obediant, and there were no significant disturbances. ${ }^{1}$ German POWs caused MG few problems. In January 1946, Munich MG declared that "There was no indication of any organized German resistance to any American authority . . . . and there was [sic] no indications of any trouble with ex-Wehrmacht men." 2

Although there was very little political disorder, there was widespread criminal disorder. Criminal issues and dilemmas were fueled by the extreme chaos, destruction, and powerlessness brought on by a brutal war. Local crimes that were illegal under both MG mandates and

${ }^{1}$ gtd. in Niethammer, Entnazifizierung 137. Citing reasons behind the lack of resistance, the German historian Lutz Niethammer (Entnazifizierung 137) points to consistent apathy among the bulk of the German population during the early occupation. See also: Ziemke, Army 354-355.

2BayHStA OMGB(Y) 10/78-1/4, Munich AHR 51. Since returning Wehrmacht POWs posed little threat their situation will not be considered in these pages. 
applicable German laws were also characteristic of crime problems throughout the US Zone. ${ }^{3}$

Certain groups of Displaced Persons posed great and innumerable challenges to law and order. They were liberated persecutees, yet suddenly became criminal offenders. This problematic status made their control a major issue for both MG and German authorities.

MG's decisiveness as military "ruler" helped to keep the problems in check. The relative security of much of the population in Southern Bavaria was generally assured, ${ }^{4}$ and order maintained. Still, even the threat of widespread criminal issues severely challenged the proper administration of the occupation. The issues were formidable, remained significant, and constitued only the first hurdles. As the German authorities became increasingly independent, they found themselves having to face an abundance of similar problems in the later occupation period.

${ }^{3}$ For brief examination of crime issues and the rural situation, see Paul Erker, "Revolution des Dorfes? Ländliche Bevölkerung zwischen Flüchtlingsstrom und Landwirtschaftlichem Strukturwandel," Von Stalingrad zur Währungreform: Zur Sozialgeschichte des Umbruchs in Deutschland, Ed. Martin Brozsat, Klaus-Dietmar Henke and Hans Woller, (Munich: Oldenbourg, 1988) 367-425. Naturally, US Army personnel committed many crimes. That issue is not illustrated in these pages, however.

${ }^{4}$ Wacker 55. 


\section{CAPITULATION, CHAOS, AND CRIME}

Plundering was a major issue in the chaotic early days of the occupation. Occupation historian Earl F. Ziemke notes that "Since the US troops, German civilians, and DPs all looted, there was some debate over whose behavior was the most reprehensible." 5 Americans could argue they had only done what armies had rightfully done for centuries. DPs could justify that they were only taking what they needed to get by. By stealing from each other, Germans had the weakest defense, yet most Germans looted only very early on and in many cases returned what they had lifted after MG pressure. 6

Looters faced the harshest penalties in the waning Third Reich. In Munich on February 16, 1945, for example, a 26-year-old woman was sentenced to death for plundering committed after an Allied bombing attack. Nevertheless, widespread plundering began well before the capitulation. ${ }^{7}$ Events signifying the sure end of Nazi authority encouraged plunderers. At about the time of the FAB revolt on April 28, plundering broke out in almost all areas of Munich. 8

The first plunderings involved all sorts of individuals, groups, objectives, and goods. On Sunday, April 29, the SS squads assigned to

5Ziemke, Army 251.

6Ziemke, Army 251-252.

${ }^{7}$ Chronik 29.

${ }^{8}$ Chronik 42 . 
guard the Führerbau (Führer Building) and the Nazi party administrative building decided to flee. Unexpectedly, the guards left both buildings on the Königplatz undamaged. In the air raid cellar of the Führerbau and connected passages the SS men left behind a collection of art "procured" during the years of triumph: 259 paintings from Dutch masters of the seventeenth century, from Paris; and 350 paintings intended for a future Hitler collection (Hitler-Sammlung) in Linz. Surprized looters snatched up the unexpected bounty. 9 Many of these works were later recovered, however. In December 1945 Munich MG issued radio and press notices to the public offering amnesty for the return of such objects. The plan proved "so successful" that MG extended it to include illegal possession of any looted art objects ("removed from any repository"), and lengthened the time for the return of such objects -- or the offer of information --to March 1, 1946.10

The looters storming these cardinal Nazi centers were not looking for art, or necessarily revenge. These suddenly fearless first bands consisted of all types: deprived forced laborers, normally proper small

9Obermaier, and Mauerer 19-20. "Kunst-Sonderführer" (Special Art Authority) Goering bought the Dutch paintings in 1942-43 from the Vichy government (19).

10BayHStA OMGB(Y) 10/78-1/3 Munich MG Monthly Historical Report (hereafter: MG Monthly) for January, 1946, 26: "The clause referring to amnesty has been strengthened to further assure the people that no action of any kind will be taken against them for the return of art works or for information regarding such works. This office received commendation from higher headquarters for instigating the action above. Approximately 35 paintings of great value have so far been recovered as well as other art objects." 
businessmen, bourgeois professionals and simple housekeepers. 11 They were hardened by countless bombings, motivated by envy and hunger, and fearful of future famine and crisis.

Provisions in storage were the main targets. Munich had long been the most important storage and transfer center in Southern Bavaria. Warehouses and cellars were stuffed with goods off-limits to, but ingrained in the consciousness of locals and forced laborers alike. 12 Wehrmacht storehouses and rations depots were the first to be ravaged. Beer cellars, department stores, customs terminals, warehouses, even apartments known to be well-stocked were then raided. Munich's Bürgerbräukeller, for example, established as the "Reichstelle für Fette und Käse" (Reich Depot for Fat and Cheese), was thoroughly pillaged of huge cheese and butter stocks. Less sensible but popular were the plunderings of wine cellars. Long lines of raiders waited with buckets and containers to get a chance at securing themselves free wine from the kegs or expensive bottles in storage. 13 Since records of provisions were poorly kept near the end of hostilities, it is difficult to estimate the extent of the first massive plunderings. In any case, most large reserves were pillaged until nearly empty. Much was simply destroyed under trampling feet or in the fray. 14

11 Obermaier, and Mauerer 20.

12 Obermaier, and Mauerer 27.

13 Obermaier, and Mauerer 28. 
The looting grew more and more extreme. Injuries and deaths increased as the stocks decreased. In the Löwenbräukeller on May 3, two people were crushed by stampeding feet. 15 In the Arzbergerkeller on May 5 , a woman was beaten to death by a fellow bottle-wielding plunderer. 16 When bolder criminals realized the larger stocks were running out, they began -- presumably in a mixture of desparation and confidence -- to hit smaller shops and businesses. Many plunderers began arming themselves, and attempts to stop them were few. 17

Munich MG, the sudden sole protector of law and order, did not act immediately against the looting. Extensive, and obvious plundering continued at least 10 days after MG arrived 18 and had begun to address other pressing problems at once. It is difficult to establish firm reasons for the delay, but some factors are clear. MG promptly announced the earliest curfew on May 1,19 but many plunderers initially disobeyed it.20 Looters carried their goods openly through main streets, under the eyes of idle MG officers. ${ }^{21}$ US soldiers reportedly allowed much of the early

14 Obermaier, and Mauerer 38. Obermaier, and Mauerer (38) presume that near the end of the war many depot keepers avoided precise inventories because they themselves were skimming from the stocks.

${ }^{15}$ Chronik 43.

${ }^{16}$ Chronik 44.

17Obermaier, and Mauerer 31.

18 Obermaier, and Mauerer 37.

${ }^{19}$ Chronik 43.

20 Obermaier, and Mauerer 27. 
looting to run their course; they stood by watching the spectacle and regarded the pillaging throngs favorably. 22

Although looting by American soldiers was not universal, there was a great deal of it. Many GIs reckoned that after the horrors and hardships they had endured they deserved their plunder. 23 From the sources at hand it appears that plundering by GIs was less prevalent in Munich than in areas with less scrupulous or effective MG detachments. Still, American authorities of all sorts looted in all areas. The practice quickly became an orchestrated art form: 24

Soldiers stationed themselves outside military government offices and intercepted civilians bringing in weapons. Tactical units posted their own contraband lists in which they included items as various as automobiles and jewelry, and the military government detachments acquired a new and, for the most part, unwelcome function as tactical commands and individual high-ranking officers requisitioned items of doubtful military usefulness through them.

Munich MG assistant chief Keller was concerned about the plundering from the start, yet optimistic about stopping it. On May 1 he discussed with Cardinal Faulhaber the possibility of setting up a "mouse trap" for the plunderers; Keller planned to steer the plunderers away from the city by having ten train cars with wine, cheese, and other provisions waiting for them at the Ostbahnhof. 25 It is not certain whether this

21 Wagner 151.

22Obermaier, and Mauerer 28.

${ }^{23}$ Ziemke, Army 136.

24Ziemke, Army 250-251.

25Obermaier, and Mauerer 150. 
action was attempted. In any case, it was at that point an already futile maneuver.

Munich MG did finally take a clear, demonstrative stand against the plundering. By May 18 MG had set up special raiding squads to constantly patrol and combat plundering. 26 MG assured the public that it would end all looting, and that plunderers would be punished sternly. MG guaranteed those small businessmen who were allowed to reopen that they could do so without having to fear looters. 27 MG for Bavaria announced that all plundered goods were to be immediately collected and returned, and pledged the security of intact storehouses and supplies. MG ordered the establishment of the "Landesamt für Ernährung und Landwirtschaft" (Land Office for Nutrition and Agriculture) to administer all remaining stocks -- one of the first offices formed on the Land level. 28

In the first months, US military courts determined punishment for the plunderers and other lawbreakers. Occupation directives had ordered the immediate closure of all courts: "extraordinary" courts and tribunals of the Nazi party as well as all ordinary criminal, civil and administrative

26 BayHStA OMGB(Y)10/85-3/5, Weekly MG Munich, May 13-20, 1945: "In conjunction with the civilian police, an American riot squad . . . . is operating efficiently in the suppression of riots, looting, black marked activities and petty crime;" Bay. Landeszeitung, May 18, 1945, 1; Chronik 51. Accordiing to Obermaier, and Mauerer (47), these teams of military police usually took along a local German policeman; this conferred some integrity to the German police who would later be on their own.

27 Bay. Landeszeitung, May 18, 1945, 1.

28 Bay. Landeszeitung, June 1, 1945, 2. 
courts. 29 By October 1945 MG developed a plan for the establishment of German courts. Under strict MG supervision the German courts gradually began to take on "milder" cases, and cases involving Germans breaking German laws. 30 The Allies abolished all German criminal laws originating in the Third Reich, and reestablished those in effect until $1924 .^{31}$ This created two systems of justice in the first years of the occupation, in which political cases and those involving the pillaging of US military property remained the domain of military courts. 32

US occupation courts were responsible for criminal and civil matters, but criminal cases played a much greater role. MG criminal courts decided cases punishable by both American and applicable German laws. 33 Foreigners and DPs breaking German laws were tried by

29From JCS 1067 in Holborn 162. Apart from Nazi courts there were hardly any functioning courts by the end of the war (Robert M. W. Kempner, "Amerikanische Militärgerichte in Deutschland," Die Freiheit des Anderen, [Baden-Baden: Nomos Verlags-Gesellschaft, 1981] 146).

30 $\underline{\text { Süddeutsche, Nov. } 6,1945,3 .}$

31 Münchner, Aug. 11, 1945, 3. On German criminal law and Allied policy, see: Hans Theodor Schmidt, "Das Strafrecht in Deutschland nach der Kapitulation," Deutschland Archiv, 4 (1971): 43-47; Karl Loewenstein, "Justice," Governing Postwar Germany (Ithaca, N.Y.: Cornell University Press, 1953) 236-262.

32 Kempner 146. By 1946 the number of cases handled by American courts fell to $27.5 \%$, by $194715.9 \%$ (146).

${ }^{33}$ Kempner 146. Military Court procedures were unique for German defendants. In contrast to German law, the Anglo-American legal principles of "innocent until proven guilty" and Habeas Corpus were acknowledged (146). 
the MG courts. MG judges had the power to hand out the death sentence. 34

The courts were busy. By August 11, 1945, MG courts had tried 15,000 cases since the occupation began. 35 During the week of August 915, 1945, for example, MG courts in Munich decided 193 cases. Most of these involved black market dealings, illegal possession of US Army goods, and false entries in the denazification questionnaires (Fragebogen). 36 In Munich, MG summary courts handling the lesser cases -- breaking curfew, trespassing, for instance -- were trying 70 cases daily in November 1945, and had already sentenced 4,000 people. 37

A series of MG proclamations warned potential lawbreakers. MG measures were designed not only to impede the possibility of disorder, but also to assure the population that the situation was firmly under MG control. Weapons or munitions in the hands of civilians, of any nationality, were strictly forbidden and severely punished. Civilians with knowledge of such items were to immediately report to MG posts or Munich police stations. 38 This policy was soon modified. As punishment MG proclaimed the possibility of a death sentence, but at the same time an amnesty period went into effect: anyone handing over munitions

${ }^{34} \underline{\text { Süddeutsche, Nov. } 27,1945,3 .}$

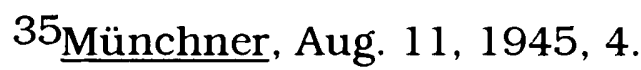

36 $\underline{\text { Münchner, Sept. 1, 1945, } 2 .}$

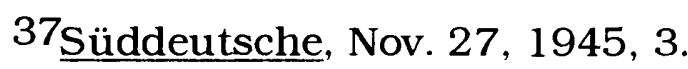

38 $\underline{\text { Münchner, June 9, 1945, } 2 .}$ 
between July 9 and July 15 was free from punishment. 39 The Münchner Zeltung demonstrated MG decisiveness by disclosing the fate of lawbreakers such as Georg Fehlmer from Laufen: the highest military court in Munich sentenced Herrn Fehlmer to 15 years in prison for the illegal possession of fire arms and munitions. Fehlmer had been hoarding the material, then burying or hiding it near his home. 40 From the day the occupation began the theft of US military property was an issue. Daily MG received reports of civilians caught stealing military goods. MG warned that anyone in possession of Allied property would be harshly punished. MG did not acknowledge the common excuse that it was not clear to the new owner that the stolen articles were Allied property; nor did MG recognize the excuse that the property was not under guard and therefore assumed to be "at hand."41 On May 17, two Münchner were sentenced to two years in prison for stealing tools belonging to the US Army. ${ }^{42}$ MG considered the situation severe enough that in January 1946 it secured the authority to employ and arm German guards to protect military installations as well as targets "merely of importance to the civilian economy." 43

39 Münchner, July 14, 1945, 2.

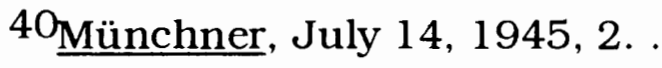

41 Bay. Landeszeitung, June 1, 1945, 2.

${ }^{42}$ Bay. Landeszeitung, May 25, 1945, 2

${ }^{43}$ BayHStA OMGB(Y) 10/78-1/4, Munich AHR, 8. This directive of Jan. 14, 1946 (BayHStA OMGB[Y] 9/18-1/4) was valid for the whole US Zone. The guards were to be "selected, employed, trained, supervised, 
MG established a form of martial law that allowed US and USsponsored authorities almost unlimited powers. In the chaos of the first months, however, even MG hegemony could be exploited, and the confusion of citizens manipulated. The massive movements of desperate, needy people in this period lent itself to many criminal schemes, and continued for quite some time. In September of 1945, MG observed the following ruse: 44

Masquerading in parts of cast-off Wehrmacht uniforms and pretending to be discharged PW's returning from the Russian occupied zone or simply posing as refugees having been mistreated by Russian occupational troops, numerous beggars are making their appearance in certain sections of Munich, especially in the less destroyed Western suburbs and in the surrounding country. They are taking advantage of the credulity of the populace in general.

After the plundering became too risky, clever opportunists contrived simple, effective, and more "refined" methods for seizing goods. Small gangs of men, for instance, donned American uniforms, or uniforms similar enough to deceive. They approached residences and brusquely announced themselves, presumably, "on orders of Military Government," or members of an authorized "anti-Nazi organization," and proceeded to search the home and "confiscate" whatever they wished. 45 The acknowledged respect for uniforms also led shrewd criminals to feign

disciplined and controlled by the head of the police force . . . in accordance with local policy (1)." In addition, MG was authorized to license private detective agencies and guard services that passed denazification directives. These men were not to be armed, not even with batons (2).

${ }^{44}$ BayHStA OMGB(Y) CO/445/1, Untitled MG Report (hereafter: MG Report) for Sept. 28 to Oct. 4, 1945.

45 Obermaier, and Mauerer 47. 
themselves as German police. By July 1946120 "phony" detectives had been caught since the beginning of the year. 46

Many "infringements" were customary for such a chaotic, desperate atmosphere. Other circumstances were more vicious. In the war years of 1939-45 there were 100 registered violent deaths in all of Upper Bavaria (Oberbayern). In Munich alone between May 1 and July 28, 1945, however, roughly 421 people died a violent death -- 155 from murder or beatings, 63 by suicide, and 120 from accidents. 47 Among these deaths -registered to the Munich police -- 302 were men, 84 women, and 35 children. A further 83 persons were victims of SS or Wehrmacht military courts, and 95 reported missing -- among these 28 children. 48

In Bavaria as a whole, the most vicious crimes decreased after roughly the first three months. Nevertheless, "lesser" crimes such as robbery, looting, and common assault continued and even increased. 49 The number of such crimes was already high: in the months of May and June, for example, 6,048 burglaries and 1,334 robberies, muggings, and lootings 50 were reported to the largely helpless and understaffed Munich police. MG Public Safety for Bavaria found that there had been an

${ }^{46}$ Chronik 180.

47Wagner 167.

48Obermaier, and Mauerer 54.

49BayHStA OMGB(Y) 10/65-1/5, Public Safety Branch Monthly Report (hereafter PSBMR), Nov. 5, 1945, 1.

50 Obermaier, and Mauerer 54. It is important to bear in mind that many lesser crimes were presumably never reported. 
increase of crimes committed by US Army personnel as well; crimes extending from "the theft of bicycles and radios to rape and felonious assault. 51

The "lesser" crimes did not dissappear over time. In 1947 Public Safety for Bavaria concluded that "arson, sex offences, narcotic offences, black market, abortion, offences against Military Government laws, fraud, theft, coinage crimes and stolen property" had all increased over the year before. 52 Public Safety crime statistics reveal that the total crimes committed in the year 1946-47 -- 410,225 -- were almost twice as many as in the year 1945-46 -- 284,666.53

In the short term, Public Safety for Bavaria concluded (in Nov. 1945) that the main deterrent to the more violent crimes was the arming of the local police: the number of incidents dropped in those areas where police were armed. Furthermore, as local police gained greater mobility -by means of patrol cars, motorcycles, and so forth -- crimes also decreased. 54 Munich MG's Public Safety also stressed the importance of arms and equipment. Moreover, reports attributed many early problems to "all sorts of vagabonds and generally unclassifiable persons" who

51 BayHStA OMGB(Y) 10/65-1/5, PSBMR, Nov. 5, 1945, 1. MG's conclusion was based on reports from German government officials (1). See also: Zink 137-138.

52 BayHStA OMGB(Y) 10/65-1/5, Public Safety Branch Cumulative Annual History (hereafter PSBCAH), July 16, 1947, 7. 53

53BayHStA OMGB(Y) 10/65-1/5, PSBCAH, July 16, 1947, 7.

${ }^{54}$ BayHStA OMGB(Y) 10/65-1/5, PSBMR, Nov. 5, 1945, 1. 
became reasonably assimilated by the end of the third month of occupation. 55

\section{DISPLACED PERSONS AND CRIME}

Much of the criminal disorder sprang from a somewhat unlikely source. Among the unfortunate multitude of the so-called Displaced Persons (DPs) were individuals accountable for many sorts of crime. 56 DP criminals included former forced laborers as well as former concentration camp inmates. DP status was peculiar, and posed special problems for MG as well as the German authorities. 57

In 1944-45, the Allies invented the term "Displaced Persons" to describe all those individuals who, because of Nazi persecution and labor policies, were in a place they did not belong. These groups required and deserved fundamental assistance from Allied authorities as victims of the Nazi regime. 58

55 BayHStA OMGB(Y) 10/78-1/4, Munich AHR 7-9.

56 Another social group, youth, showed a marked, though not as large part in crime activities as DPs in the post-war period. Youth crime began to increase in 1946 (Chronik 146). On causes, see Barbara Willenbacher, "Zerrüttung und Bewährung der Nachkriegs-Familie," Von Stalingrad zur Währungreform: Zur Sozialgeschichte des Umbruchs in Deutschland, Ed. Martin Brozsat, Klaus-Dietmar Henke and Hans Woller, (Munich: Oldenbourg, 1988) 596-618.

57 The DPs should not be confused with the refugees -- mostly German nationals -- flooding into Germany during this period from the east. 
The DPs constituted a definable group, but structurally they were an "amorphous" one of individuals transferred and imprisoned against their will. Within the category of DPs were two types: on the one hand forced laborers and foreign workers; on the other liberated persecutees 59 -- political prisoners, concentration camp victims, and so forth. One relatively homogenous DP characteristic -- age -- was precisly due to the fact that many DPs were forced laborers selected for youth and stability. DPs constituted a rather solid age group instead of a normal mix of ages between various social levels 60 Precise, contemporary age figures for 1945 are nevertheless difficult to ascertain for DPs as a whole. Rough estimates of Polish DPs suggest that there were more male than female DPs; that the men were mostly between 15 and 35, and the women between 25 and 39.61

The Allied Powers naturally assumed the enormous responsibility of caring for and repatriating the DPs. Still, who exactly was in charge of this reponsibility had to be clarified during 1945. According to the UN charter of Nov. 9, 1943, the DPs were displaced nationals of the United

58Wolfgang Jacobmeyer, "Die Displaced Persons," Flüchtlinge und Vertriebene in der Westdeutschen Nachkriegsgeshcichte: Bilanzierung der Forschung und Perspektiven für die künftige Forschungsarbeit, Ed. Rainer Schulze, Doris von der Brelie-Lewien, and Helga Grebing, (Hildesheim: Lax, 1987) 175. In this piece Jacobmeyer indicates the lack of research on the DP phenomenon. For consideration of Jewish DPs, see Wetzel 327-366.

59 Jacobmeyer 175 .

60 Jacobmeyer 175-76.

61 Jacobmeyer 176. Jacobmeyer (176) attributes the higher female age to "rational" Nazi criteria for forced labor: older female laborers were less inclined to become pregnant. 
Nations. 62 Accordingly, the United Nations Relief and Rehabilitation Administration (UNRRA) was to care for DPs in Germany and attend to their repatriation after the capitulation. Initially, however, UNRRA personnel assisted the Allied armies in DP matters. UNRRA teams were under the command of Allied Supreme Commander General Eisenhower, and the US Army assumed supply responsibilities for DPs in Germany. 63

Originally, MG personnel were only to care for and locate DPs during the combat period. The administration of DP assembly centers in the rear zones was to be gradually taken over by UNRRA personnel ready for special assistance. Nevertheless, the surrender in May suddenly liberated MG administrative staff as well as Allied transport and care capacity for DP matters. ${ }^{64}$ At the time of the surrender there were an estimated $5,800,000 \mathrm{DPs}$ in the occupation areas as a whole. $3,260,000$ of these were repatriated by July 2, 1945.65 In summer and fall 1945 a daily rate of 33,000 DPs were transported to their homes. By 1946 repatriation slowed down tremendously, and for the whole year reached only about 500,000 DPs. 66 In the American Zone itself, the total number

62 Holborn 13.

${ }^{63}$ Holborn 13 . The three volume UNRRA history gives only scant mention of UNRRA and the DP issue within Germany: UNRRA: The History of the United Nations Relief and Rehabilitation Administration, Ed. George Woodbridge, 3 vols. (New York: Columbia University Press, 1950).

${ }^{64}$ Holborn 48.

65 Münchner, July 14, 1945, 1.

66 Jacobmeyer 177. 
of DPs in UNRRA assembly centers in May 1946 was down to 348,000 -163,000 Poles, 87,000 Balkans, 43,000 Jews and 55,000 of various origin. 67

The German-American historian Hajo Holborn gives MG credit for solving much of the early DP repatriation problem. Since events developed very quickly after May, the UNRRA teams became a factor in DP matters much later than planned. 68 How soon the DPs would be turned over to the civilian UNRRA authorities was left up to the individual MG commanders in the field. In the confusing period at the end of hostilities, when MG found itself responsible for many challenging tasks at once, this meant that the turnover of DPs to UNRRA varied greatly. 69

In May 1945 Munich MG staff and tactical army DP teams had full responsibility for DP care and repatriation. At that time there were than 300 camps or "concentrations" of DPs in the Munich area. Four of the largest camps consisted of 7,000; 6,500; 4,000; and 1,000 respectively. It is difficult to establish the exact number of DPs at a given time, since repatriation proceeded at such a rapid rate during this time. Nevertheless, MG estimated the total amount of DPs to be about 65,000.70 The following list from MG reports details the various nationalities of the DP as of May 26, 1945:71

67Wetzel 346.

68 Holborn 48.

69 Holborn 13. 
Russians

Poles

French

Belgians

Dutch

Yugo-Slavians

Czechs

Greeks

Jews (all nations)

All Others

In hospitals

Total:
25,183

8,391

9,242

1,841

1,564

1,392

1,339

917

1,762

2,585

714

55,930

MG estimated evacuations by the same date as follows: 72

Russians

Poles

Czechs

French, Belgian and Dutch

Total:
1,147

2,322

206

17,898

-....-

21,573

As the numbers illustrate, most of the DPs from Western European countries were readily repatriated in the first months. Russian DPs, although numerous, were promptly transported home as well. Already by the middle of June, MG reported an insufficient number of Russian DPs to complete the "rail quota" of 2,000 persons. In the last week of June, however, there was an "unprecedented influx" of Russians from other sites in the American Zone that "taxed DP camp facilities to the limit." Still, this was temporary, as Munich was a necessary railhead: in one telling example more than 30,000 Russians were sent on within 24 hours

70 BayHStA OMGB(Y) 10/78-1/4, Munich AHR 149.

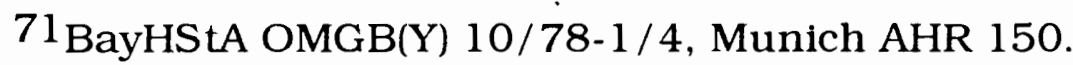

72 BayHStA OMGB(Y) 10/78-1/4, Munich AHR 150. 
after their arrival. 73 By July the number of DP camps had been reduced to 200.74 By Sept. 1945 the DP population totalled 29,389.75

The job of caring for the DPs put a great burden on MG. Principal difficulties were locating housing and providing food. MG attempted to assemble DPs in the largest concentrations possible to simplify administration, attain more effective security, and to assure economy in food distribution. 76

Continuous reorganization in 1945 caused shifts and a lack of clarity in responsibility for the DPs. The regular US Army relieved the Munich MG detachment of some DP responsibilites by the end of July. 77 After October 1945 UNRRA took over the administration and care for the DP camps. 78 Complete termination of MG responsibility for DP matters was made official on December 31, 1945. Nevertheless, Munich MG felt it necessary, "temporarily at least," to maintain a DP bureau, since the Munich Rathaus where MG was headquartered was "an obvious focal

73BayHStA OMGB(Y) 10/78-1/4, Munich AHR 153.

74 $\underline{\text { Münchner, July 7, 1945, } 2 .}$

75BayHStA OMGB(Y) 10/78-1/4, Munich AHR 153.

76 BayHStA OMGB(Y) 10/78-1/4, Munich AHR 150.

77BayHStA OMGB(Y),10/78-1/4, Munich AHR 153. On the regular army's role in DP matters, see: Ziemke, Army 284-290.

78Wetzel 346. In Munich UNRRA established a headquarters for the complete US Zone, and in the Deutsches Museum a university for DPs (346). 
point" which DP's sought out for advice, assistance, and information. 79 A visiting MG observer lamented in December 1945 the lack of "centralized control" between the various branches and agencies responsible for DP affairs, a tense situation that was straining the efforts of MG detachment staff burdened with an increased work load despite fewer personnel. 80

Allied leaders had hoped to resolve problems of DP care and repatriation by September of 1945.81 The UNRRA and MG personnel managing DP matters were soon faced with problems of a different and more complex nature, however. Many DPs viewed the regimented "administration" of their lives and their condition -- despite the clear advantages in comparison to life in the Third Reich -- as continuation of their former persecution and severe existence. 82 Some DPs remaining after the first couple of months did not want to comply with repatriation, 83 and avoided returning to their former homes. Polish DPs posed a special challenge in this respect. Of these former civilian forced laborers and soldiers, more than 500,000 remained in the British and American Zones as of the end of August. Many refused to be repatriated, and held out for transport to other destinations and new homes. 84 29.

${ }^{79}$ BayHStA OMGB(Y) 10/78-1/3, MG Monthly for January, 1946,

${ }^{80}$ BayHStA OMGB(Y) CO/445/1, Op. Report, Dec. 19, 1945, 5-6.

81 Münchner, July 14, 1945, 1.

82 Jacobmeyer 178 .

83 Holborn 48. 
Inside the camps some DP groups began to defiantly organize themselves both politically and militarily, forcing US occupation forces to take drastic actions. 85

The greatest dilemma for occupation and German authorities was the DPs' involvement in crime. Not all, or even most of the DPs were criminal. It is nevertheless a fact that in Munich and throughout the US Zone DPs played a significant role in criminal activities. 86 It is impossible to establish the exact impetus for DP criminality, but many motives can be presumed: hate, fear, revenge, hunger -- all stemming for years of deprivation and brutality; the frustrating idleness of the DP camps; in addition perhaps an expectation among some -- consciously or not -- that they would be able to utilize their liberated status for unworthy ends.

Among the DPs remaining after the first few months of repatriations were many doubtful characters. In a telling example, MG in nearby Regensburg had 240 DPs complete a questionnaire similar to the Fragebogen required of Germans. Results revealed that 40 percent of

${ }^{84}$ Münchner, Sept. 1, 1945, 3. This Polish problem was significant enough that General Eisenhower and Field Marshal Montgomery felt it necessary to hold talks on it at the end of Aug. 1945 (3).

85For example: In Munich on February 14, 1946, heavily armed US tactical troops raided specific camps for Polish and Yugoslavian DPs. The units seized numerous documents and weapons, and in the Yugoslavian camp found that many DPs bore identification cards for the "Royal Yugoslavian Army of Bavaria" (Chronik 141).

86 For general consideration of the DPs and crime, see: Ziemke, Army 354-358. 
those questioned, if German, would have been deemed "unemployable in responsible positions and possibly subject to arrest." 87

MG reports are filled with observations on lawless DPs. MG for Munich summarized the issue with the following passage: 88 "The greatest problem in the early days [of the occupation] was the vast number of DP's [sic], newly liberated persecutees, and criminals who had been indiscriminately released along with the political persecutees, all of whom roamed the land and ravaged the towns."

German officials came to the same conclusions. The criminal investigations branch of the Munich police recorded the following crimes for the period of May until Nov. 1945, and the percentage committed by foreign nationals: 89

\begin{tabular}{lrc} 
Crime & Total & $\begin{array}{c}\text { Percentage Committed } \\
\text { by Foreigners }\end{array}$ \\
\hline Murder & 422 & $75 \%$ \\
Robbery & 1,617 & $80 \%$ \\
Plundering & 834 & $70 \%$ \\
Black Market & 1,019 & $75 \%$
\end{tabular}

Figures for 1946 reveal that the percentage of foreigners committing the most vicious crimes (murder, robbery, extortion) remained over 70\%,90 despite the diminishing number of DPs.

DPs were responsible for many of the early, more vicious crimes, and were at the "vanguard" during the early plundering. Prominent

87Ziemke, Army 356.

88 BayHStA OMGB(Y) 10/78-1/4, Munich AHR 5.

${ }^{89}$ Wacker 55. It is unfortunate that these crime figures do not clarify which sort of the various DPs were most criminally active.

90Wacker 55. 
among criminal DPs were the Poles. In Nov. 1945, MG's Public Safety Branch for Bavaria explained the crimes of the previous month in the following terms: "The bulk of [the] crimes were attributed to Displaced Persons [sic], particularly Poles and Hungarians . . . the incidence was heaviest in areas adjacent to Displaced Persons camps. 91

DPs remained criminally active for a long time. By February 1946 MG judgment of DP activity was much the same, in spite of repatriation efforts: 92

The looting and plundering reports attributed much of such activities to Displaced Persons. Information received indicated that the bulk of the persons, so engaged, have either refused to return to their native land or have been repatriated and have returned.

Already by Sept. 1945, Munich MG had reached the following conclusion:93

DP's remained the major offenders in all crimes, $46 \%$ of all arrests made in the last week were established as DP's and it is estimated that $90 \%$ of all major crimes were committed by them.

In explaining a rising rate of crime incidences in 1946, Munich MG maintained that criminality was "largely due to the activities of DP's and other foreigners lodged in camps and lagers [sic]." 94 In clarifying the main offenders, MG contended that "the Poles continued to constitute the largest class of DP offenders. "95

${ }^{91}$ BayHStA OMGB(Y) 10/65-1/5, PSBMR, Nov. 5, 1945, 1.

92BayHStA OMGB(Y) 10/65-1/5, PSBMR, Feb. 8, 1946, 2.

93 BayHStA OMGB(Y) 10/78-1/4, Munich AHR, 49.

94 BayHStA OMGB(Y) 10/78-1/4, Munich AHR, 9. 
Control of DP criminality was complicated by special problems. The use of American uniforms or similar dress allowed criminals to easily and often exploit the almost unlimited power of US occupation forces. In October 1945, MG and the German police found themselves constantly occupied with the following sort of situation: "DP's dressed in American uniform, continued their daily terror prowls, robbing and looting. One gang was broken up, the ring leader in jail, and an intensive investigation was made by the MP's and German Police."96 It is not clear in all cases if MG or army personnel -- presumably when they staffed DP camps -- originally provided the uniforms.

In any event, MG was concerned about the uniforms for another reason: reports of many crimes by DPs in American uniform were charged to the US troops. 97 Such circumstances certainly did not lend themselves to a greater trust of MG among the local population. By November Munich MG began an "aggressive campaign" to limit unauthorized persons from wearing US uniforms, and found the measure effective. 98

To some degree the occupiers' experiments in security invited such consequences. A common practice was employing DPs as guards, especially Poles. In Munich, the units appear to have been much too

95 BayHStA OMGB(Y) 10/78-1/4, Munich AHR, 52.

96 BayHStA OMGB(Y) 10/78-1/4, Munich AHR 50.

97BayHStA OMGB(Y) 10/78-1/4, Munich AHR 49.

98 BayHStA OMGB(Y) 10/78-1/4, Munich AHR 51: "Offenders were stripped of the uniform and received jail sentences." 
eager for MG standards: "A high degree of violence is exhibited by Poles employed by the US Army as guards."99 In January 1946, the Polish guards remained the "most troublesome group." They were still in American uniform, by then modified by only a small shoulder patch. 100 Significantly, even by March 1946 the problem had not been rectified:101

The principal obstacle to efficient policing continued to be the Polish units wearing American uniforms. Until this situation is corrected confusion will exist as certain of these persons misuse the immunity of the uniform for their criminal purposes.

Despite stricter MG measures, DP criminality was a problem that would not go away. In Bavaria between June 1 and October 30, MG courts (solely responsible for prosecuting DPs) held 2,700 trials for serious crimes such as murder, robbery and looting. 102 MG courts pronounced harsh sentences. In December 1945, for example, the highest US military court in Munich sentenced two Greeks to death. On July 11 they had intentionally strangled a 62-year-old Munich woman and pillaged her apartment. 103 By November 1945, Public Safety for Bavaria felt the problems significant enought to receive authorization to use US Army personnel as armed guards at specific DP camps, especially in areas where crimes of looting, rape and murdering were widespread. 104 In the

99BayHStA OMGB(Y) 10/78-1/4, Munich AHR 9.

100 BayHStA OMGB(Y) 10/78-1/4, Munich AHR 51.

101 BayHStA OMGB(Y) 10/78-1/4, Munich AHR 52.

102 Ziemke, Army 358.

${ }^{103}$ Süddeutsche, December 7, 1945, 3. 
same period, Munich MG assessed the DP situation in a familiar manner but offered an insightful view: 105

Forty-two percent of the crime in Munich is caused by nonGermans, who constitute less than $5 \%$ of the total population. Gangs of Frenchmen have been involved in the forging of food requisitions. Poles have been going to Poland, selling clothing issued here, and returning to Munich with huge sums in marks, and the hope of obtaining a new clothing hand-out. It has been recommended to higher authority, in view of the above reported incidents, that the non-Germans privilege of trial only by Military Government courts be withdrawn, or the policy of developing German responsibility for self-government will be undermined.

The above recommendation remained a recommendation.

DP criminals were a defiant and especially violent group. This factor made their arrest much more difficult, especially for German police who were relatively impotent in DP matters. Despite MG regulations, DPs were often armed and did not willingly yield to arrest. Because of this, MG assessed that the already high amount of crime reported did not reflect the "true picture" of crime. 106

It is significant that not all former concentration camp inmates were law-abiding. Some DPs who were former prisoners of concentration camps -- although themselves victims of vicious brutality -- took part in robberies, plundering, and the black market. Many of these types took it upon themselves to exploit MG power and the helplessness of the occupied by illegally seizing goods and occupying housing. Some of the alleged victims had not been in concentration camps at at all; some were

${ }^{104}$ BayHStA OMGB(Y) 10/65-1/5, PSBMR, Nov. 29, 1945, 2.

105BayHStA OMGB(Y) 10/78-1/3, MG Monthly for November $1945,5$.

106 BayHStA OMGB(Y) 10/78-1/4, Munich AHR 51. 
common criminals and murderers who were liberated along with the Jews and political prisoners. Others had served in the camps as henchmen and "agent provocateurs" for the SS. 107

There was confusion and fear among the local population concerning which DPs had been politically persecuted, who of these were authorized by MG, and how effectively DPs were being controlled. The tense situation led to new measures. By September MG ordered the preparation of official identification cards for former concentration camp inmates that distinguished those who had been truly persecuted on political grounds from those criminal elements exploiting former camp inmate legitimacy. 108 At the same time, MG used its media to warn the public of "Two Types of Camp Inmates" ("Zwei Arten von KZ'Lern") 109 and clarified who was to be trusted in strict occupation matters and measures.

Persistent pessimistic gossip clouded clear impressions of actual success in regulating concentration camp inmates. Rumors ran rampant among local Germans in November that MG would tolerate former forced laborers and concentration camp inmates unleashing a wave of plundering and looting around November 8 and 9 , on the anniversary of the 1938 "Krystallnacht" (Crystal Night). The rumors were without

107 Münchner, Sept. 8, 1945, 4.

${ }^{108}$ Chronik, 84; Münchner, Sept. 8, 1945, 4.

109 Münchner, Sept. 8, 1945, 4. 
foundation, yet MG, the German police, and a group of former camp inmates all clarified publicly they would not permit such activities. 110

Many of the crime problems in the early occupation were direct products of brutal strife. Hideous strains on human dignity, morals and willpower ensued from the unforgiving devastation and utter breakdown of administration and infrastructure. The melee of crimes expressed hate, revenge, naked fear and cold opportunism. Under the circumstances, it could easily be argued, MG performed an admirable job in holding the possibility for crimes in check. Still, as the example of the looting situation in Munich reveals, MG appeared to act selectively early on in curbing certain threats to law and order.

Tentative, unclear policy led to the DPs' ill-defined status and confused control. Many DPs, once victims themselves, fended for themselves or were assembled in camps at least symbolically similar to ones in which they languished for years. For many DPs the pain and want continued unabated after liberation, matched only by their newfound capacity to lash out and practice blunt malevolence at a savage world. Such ferocity of temper created major challenges for occupation authorities and near hopelessness for restrained German police officials.

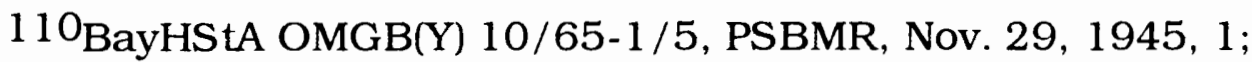
Chronik 98. 


\section{CHAPTER VI}

\section{LAW AND ORDER ISSUES II: THE BLACK MARKET}

In the early post-war black market, significant elements thus far described in this study were present: MG's commanding role; uncertain German police authority; the effect of the plundering; crime and the DPs.

The black market was a peculiar type of crime. The black market was an ironic "institution" that began to expand during the war and easily survived Nazi measures to tame it. Black marketeers mocked their persecutors and persisted to thrive into the chaotic early occupation and on. One could argue whether or not, under the circumstances, black market dealing was really a "crime" at all. Black marketing permeated all sectors of a bitterly ravaged society and involved Germans and GIs, MG officers and DPs alike. For many common, normally law-abiding citizens, the black market was the only way to survive.

Black trading was a significant and threatening problem nevertheless. Unofficial trading interfered with official efforts to create an economic base and provide necessary levels of nutrition. Many black marketeers were heartless opportunists, some cruel and violent criminals.

Efforts to curb the black market were mostly ineffectual or naively deemed successful. In combating the Munich black market, MG at first assumed the usual imposing role, but soon left most direct engagement 
up to the German police. Did MG not recognize the intensity of the black market, or did it ignore the German police's inability to confront it? Perhaps MG did not consider itself ultimately responsible for the problem? The best explanation for this enigmatic issue appears to involve a combination of all these considerations, and more.

\section{THE NATURE OF THE BLACK MARKET}

To a great extent the black market resulted from the lack of sufficient provisions and goods, and did not begin at the capitulation. Throughout the Second World War there had existed in Europe a robust and consistent "shadow economy." In many cases the goal of this form of black marketeering was to evade Nazi economic controls (Zwangsbewirtschaftung) by circumventing rations restrictions. SS security officials described three rough criminal classifications of the wartime shadow economy: bartering (Tauschhandel); illicit trading (Schleichhandel); and black marketeering (Schwarzhandel). ${ }^{1}$

Stern measures did not impede the growth of the black market inside the boundaries of the Third Reich. Stricter wartime controls only led to consistently rising economic "crimes." From 1939 to mid-1943, 59,253 violators were sentenced in the areas of the German Reich. The offences violated the War Economy Decree (Kriegswirtschaftsverordnung) of September 4, 1939, and the Consumption Control Criminal Ordinance (Verbrauchsregelungsstrafverordnung) of April 6, 1940. The number of

${ }^{1}$ Boelke, Willi, Der Schwarzmarkt 1945-48: Vom Überleben nach dem Kriege (Braunschweig: Westermann, 1986) 11-13. 
offences jumped markedly after 1941; only 2,946 of the above cases were committed in 1939-40.2

In the last years of the war, the shadow economy grew even more. Many of the simplest but necessary household items could only be found on the black market. The undeniable shadow economy led to the gradual legalization of lesser violations. Later Nazi economic decrees acknowledged the existence of a black market and toned down punishment for minor violations. ${ }^{3}$ Guidelines for combatting bartering and illicit trading from August and December 1944 ignored the "Letztverbraucher" -- the ordinary participant on the edges of the shadow economy - as long he bought or traded for personal usage and "in modest amounts." Interestingly, the same decrees allowed foreign forced laborers -- the later DPs -- to trade inside their camps. 4

Despite the wartime growth of the black market, it is significant that, even under rationing, the levels of foodstuffs, consumer goods, and nutritrional standards had been largely assured. Significant amounts of goods arrived from the occupied lands to fill gaps. Increased bombings near the end of 1944 caused rationing to become more pronounced, yet the nutritional level for the "normal adult consumer" of 2,000 calories per day was still maintained. 5

2 Boelke 16.

3Boelke 21.

${ }^{4}$ Boelke 28.

5Fuchs, Margot, '“Zucker, wer hat? Öl, wer kauft?' Ernährungslage und Schwarzmarkt in München 1945-49," Trümmerleben. Texte, 
Unconditional surrender suddenly destroyed the ability to provide an adequate standard of goods and provisions. Chaos and destruction brought about the complete breakdown of the nutritional and supply infrastructure. The division of German areas, the loss of eastern lands and the devastation of the transport network compounded problems. The sudden lack of forced laborers in the agrarian economy posed another challenge. 6 Plundering also took a great toll. In Munich, for instance, the pillaging of the first days emptied almost completely the provision stocks for the city. These supplies were intended to cover the population for several weeks. ${ }^{7}$

In matters regarding food supply, MG assumed a supervisory role from the beginning and appointed Germans to administer the situation. MG's response to the food emergency illustrates the early reliance on capable and effective figures. Munich MG immediately -- on May 5, 1945, days before MG controlled the widespread plundering -- appointed Dr. Ernst Rattenhuber to head the Landesamt für Ernährung und Landwirtschaft (the Land Office for Nutrition and Agriculture). Like other early Munich appointees, Rattenhuber was made responsible for conditions in all of Bavaria. MG made it clear to Rattenhuber he was only a temporary "tool" (Werkzeug); MG pressured him to devise an

Dokumente, Bilder aus den Münchner Nachkriegsjahren, Ed. Friedrich Prinz and Marita Krauss, (Munich: Deutscher Taschenbuch Verlag, 1985) 103. The 2000 calorie standard was not met again until 1950-51 (103).

6Fuchs 103.

7Fuchs 105. 
immediate solution to the food shortages. Rattenhuber was threatened with a war crimes indictment if he could not fulfill his task. 8

Rattenhuber's assignment was daunting. 9 Rattenhuber's office was to administer all the remaining stocks of goods and provisions. The office formulated a new rationing system which at first remained the same as before the surrender: Bavarians continued to use wartime ration cards (including the swastika printed on them) and obey the established distribution periods. Thereafter a monthly ration rate -- according to user category -- was set by the Wirtschaftsrat (Economic Council) supervised by the Allies in Frankfurt. 10

The Wirtschaftrat's assigned goal of 2,600 calories for the average adult consumer was never reached in Munich. At the end of December, 1945, the average was only 1,500 calories. 11 Thus the nutritional and survival possiblities offered by the black market made it essential to many. The following examples are illustrative. In 1946, a common Munich pensioner recieved 45 marks a month. From this amount, he could purchase with a legal ration card whatever food was available for

8 Niethammer, "Besatzungsmacht," 177. Rattenhuber, a private land owner and monarchist, had administered the crown estates of the Bavarian princes. He had impressed MG by taking the initiative immediately before the occupation in attempting to secure the dairy supply in his own community (177-78).

${ }^{9}$ As it turned out, the politically problematic Rattenhuber -- he had Nazi as well as monarchist connections -- did not last in his post because of the intensified MG denazification process.

10 Fuchs 104.

11 Fuchs 104. 
15 marks. Typical rent was 30 marks. His money now gone, he could not buy heating material legally or on the black market. A skilled worker with two children earned 200 marks a month. That amount covered dinner for one in a decent restaurant. 12 In such an environment there were two realities, and two economies -- the legal and the black.

Of course, the reasons for the black market were not simply nutritional. Any sort of trading outside the normal market, supply, and price structure was black market trading, and the ultimate effects of this total unofficial market were not positive. Illegal commerce did not necessarily help ease conditions. The buying and selling of items outside the rationing structure, for example, hindered supply efforts in the long run and undermined the price structure. 13

Many black marketeers were obviously not trying to survive, or help people survive, but to prosper. Many of the criminals and plunderers discussed previously found the market a logical outlet, and the preferred arena. Accordingly, black market sources were manifold. German historian Willi Boelke has ascertained that the post-war black market derived merchandise from the following nine general sources: ${ }^{14}$ 1) supplies -- especially food and luxury items -- of the occupation forces; 2) foreign products smuggled in; 3) assets of consumer goods and

\section{${ }^{12}$ Chronik 212.}

13 Fuchs 112 .

${ }^{14}$ Boelke 138 (translated by this author). The numerical sequence does not correspond to a quantative order; such a listing would be conjecture at best. 
valuables from the German population; 4) routinely produced industrial and commercial goods; 5) normal agricultural production, surpluses, and unfulfilled delivery quotas; 6) embezzled or squandered goods as well as leftover inventories from regular trade and commerce; 7) cached rations, bartered produce, and material assets; 8) belongings and provisions obtained by robbery, theft, plundering and fraud; and 9) wares procured by counterfeiting (from falsified ration cards, for example). Black trade was "big business." At the end of 1946 roughly $30 \%$ of industrial production -- not including heavy industry -- entered the black market directly. 15

Despite the severe consequences for possessing, selling, or trading US military property, the black market thrived from the availability of US goods. In September 1945, General Eisenhower found the situation extreme enough to fortify measures against the "dangerous" and growing trade in US goods, both for foreigners and German citizens. All civilians had to prove their rightful ownership of US property, and were threatened with the harshest punishment. 16

Many goods could simply not have reached the black market without the participation of the occupier. US soldiers as well as higher officers abused their powerful status 17 and played a substantial role in

15 Fuchs 113.

16 Münchner, Sept. 22, 1945.

17 See: Davis 148-161. For depiction of an exceptionally corrupt -politically and criminally-- MG detachment commander who went largely undiscovered, see the example of Eichstätt's Maj. Towle in Peterson 306314. 
the black market, utilizing their impunity from the German police and creating the widespread availability of US goods and vehicles. Faced with dull occupation routine, GIs and officers found the black market was the only real game to play; "virtually every occupation soldier was faced with the maximum of opportunity and the maximum of temptation." 18 Although most Americans denied it, black marketing was so widespread on a small scale that those who did not practice it were viewed as “peculiar' or 'freaks." 19 Far less prevalent but a problem nevertheless were major black market rings involving higher ranking officers and GIs alike. 20 The bribery of US personnel was also widespread, and some German employees of MG exploited their influence in return for certain favors. 21 The endless cases reported in MG media served as a warning, 22 but also hint at all the corruption that was never discovered.

Considerable US military involvement in the black market continued until the currency reform of 1948 despite continual measures, 23 and had at times a critical impact on occupation operations

18 Davis 149.

$19_{\text {Zink } 138 .}$

20 Zink 139.

$21^{1}$ Various examples in Süddeutsche, Oct. 23, 1945, 4.

22 For example, the case of Hans Klein: Klein was found guilty of attempting -- with the help of a German employee of MG -- to bribe a US military criminal court officer into freeing his father, a restaurant owner arrested for the illegal posession of large stocks of US cigarettes and provisions stored in his restaurant (Süddeutsche, Oct. 12, 1945, 3). 
and finances. Occupation chroniclers such as Harold Zink maintain that the Americans' widespread black marketing had an even greater impact on the occupation than simply economic or operational factors. 24 Many Germans became far less impressed with their occupiers' abilities, lofty aims and strict measures when they witnessed daily the widespread duplicity the Americans practiced by enjoying the sour fruits of the black market.

Resolute black marketeers repeatedly adapted themselves to market conditions. Directly after the capitulation, money -- reichsmarks, military currency, and dollars -- played a major role on the black market. Money changing paid off, and goods brought enormous profits; prices were well over those in normal conditions. The amounts fluctuated greatly according to supply and demand. 25 By the end of August 1945 money was losing significance, however, and the cigarette was fast becoming the prime currency as well as the preferred product. 26 American cigarettes were highest in demand. Coffee also held steady worth. 27 As in the Third Reich shadow economy, many items and services were simply bartered. The intrinsically unregulated and fluid

23 Davis 151-161; Boelke 127-129. US soldiers found guilty of black market dealings could be immediately sent home (129) -- perhaps another reason why so many were involved!

${ }^{24}$ Davis 138.

25 Fuchs 113.

26 By the middle of August every citizen of both sexes over 18 years of age received a regular ration of 20 cigarettes (Chronik 69 ).

27Obermaier, and Maurer 72. 
nature of the black market made it extremely difficult to control or impede.

\section{CONFRONTING THE MUNICH BLACK MARKET}

In Munich the already existing black market continued almost without pause after the capitulation at various sites. The Gestapo had indifferently monitored a black market among foreign forced labor in and around hospital facilities at the north end of the Sendlinger Tor-Platz. During May 1945, without police controls and little possibility of arrest, this area developed into a major black market center. 28 Other black market areas suddenly emerged, including the Hauptbahnhof (main train station). Pubs, restaurants and hotels began to attract black traders as well, especially in inclement weather. 29

At first the black marketeers appeared freely in the open. It is impossible to determine the degree to which the unchecked plundering contributed to the black marketeers' sudden confidence, but a connection is presumed. Moreover: the circumstance that many black marketeers were DPs who suddenly found themselves liberated and considered themselves relatively free from (especially German) control offers an explanation for the unexpected casualness. Another factor is that MG was only beginning to establish its authority in May.

28Obermaier, and Maurer, 46.

29Fuchs 115. 
In any case, the relative confusion afforded black traders much latitude. German laws regulating the black market remained in effect but appear to have held little actual sway over lawbreakers. In June 1945, the desolate Munich criminal police observed defiant black marketeers setting up umbrellas, laying out their wares, and conducting games of chance offering huge money prizes of bundled reichsmarks. 30

Not until June did MG or German authorities seriously attempt to address the situation. US personnel participated directly early on. They remained available for assistance if necessary, yet in combatting the black market MG soon took on an "advisory" role. Although issues remained which MG influenced directly, it soon left the routine control of the black market largely up to the police and the municipal authorities.

Concerted efforts to combat the black market began in July 1945. MG determined that black market operators were indeed violating German criminal laws, and German police surveyed the extent, locations, sources and possible legal violations (both US and German) of black market activities. 31 Combined units (named "flying squads" by MG) of German and military police repeatedly raided black market areas. Munich's famous Viktualienmarkt, the site of a thriving black market, was raided hourly or more, so that soon MG could report "negative" black market activity. 32 The first black market case -- illegal possession of

30Fuchs 113.

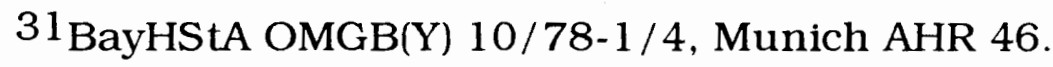


rationed German meat -- resulted in a guilty sentence and punishment of 1 year imprisonment including hard labor. 33 By the end of July, 121 persons had been arrested for black market crimes, and 162 interrogated. 34

The apparent mastery of the situation continued. In August MG attributed success in fighting the black market to the following measures: "The dispersing of large gatherings . . . the circulation of criminal police in civilian clothes wherever people gather . . . the presence of cruising motorcycle patrols .... [and] the use of placards and a sound truck as warning device." 35 Twelve squads of German police were patrolling during the day and an MG sound truck roamed the streets announcing warnings against black market activity. 36

According to the its own reports Munich MG considered these efforts highly successsful. Already in mid-August reports claimed that "the backbone of the Black Market [sic] was broken," and attributed further success to the decrease in DPs, "offering proof that these people are the main violators of Price and Food Control Laws." 37 By September MG reported firm control of the situation and that "[no] American goods

32 BayHStA OMGB(Y) 13/142-1/7, MG Weekly, July 3-20, 1945.

33 BayHStA OMGB(Y) 10/78-1/4, Munich AHR, 46. In this period black market cases were handled by $M G$ courts.

${ }^{34}$ Boelke 223.

35BayHStA OMGB(Y) 13/142-1/7, MG Weekly, Aug. 10-17, 1945.

36 BayHStA OMGB(Y) 10/78-1/4, Munich AHR 46.

37 BayHStA OMGB(Y) 10/78-1/4, Munich AHR 48. 
were in evidence." October reports concluded that large-scale black market activity was over, although "the small peddler will continue to operate as long as there are controlled items." MG was certain that "the continued application of pressure" would prevent future black trade from "getting out of hand." 38 As far as MG was concerned, the situation was under control, and subsequent reports give scant reference to any change in the black market situation.

MG misjudged the strength of the black market. The black market was by no means under control in the fall of 1945, and the "operators" certainly not stagnant. Between September 1 and October 19, 1945, over 650 black marketeers were apprehended and sentenced in Munich, 39 an average of $12-15$ persons a day. 40 This large figure also hints at the violators who were never caught.

It was a "dubious" victory. 41 Munich's black marketeers were remarkably tough, flexible, and determined, and quickly adapted to the situation. 42 In reality, the black market had only been prodded from public view. Dealings began to take place more and more behind closed doors. Open-air locations remained for contact purposes; potential

38 BayHStA OMGB(Y) 10/78-1/4, Munich AHR 49-50.

${ }^{39}$ Chronik, 92; Süddeutsche, Oct. 19, 1945, 3.

40 Süddeutsche, Oct. 19, 1945, 3. Of those 650 arrested, the youngest was 13 , the oldest 72 . The number of young people and women involved in the black market was in this period relatively small (3).

41 Fuchs 114.

42 Boelke 92. 
traders would meet to decide on the goods and the price, and then conduct the actual business in a safe place. 43 Munich's huge beer halls were perfectly suited for completing or arranging transactions. Other methods soon caught on: clever traders had much success by reappearing immediately after a raid, and the defiant tactic became a common practice. ${ }^{44}$ Some black marketeers organized their own bicycle patrols to warn of impending raids. 45 MG officers were presumably aware of the dubious environment. A black market investigation in September revealed, for example, that "meat, vegetables, coffee, and cigarettes, are being sold by the house-to-house canvassing method." 46

The question remains whether MG really was concerned about, or considered itself responsible for taming the black market. Confident Munich MG soon left the task of combatting the black market to relatively independent German police units. In July, the Munich police -in the midst of reorganization and working closely with US Military Police -- had started to act against illicit trading by ordering its somewhat unsure patrolmen to clear any public gathering in known black market areas. 47 Soon MG demanded it do more, and advised the

43Fuchs 114.

${ }^{44}$ Boelke 94.

45Fuchs 115.

46 BayHStA OMGB(Y) CO/445/1, MG Report for Aug. 30 to Sept. $6,1945$.

47 Boelke 94 . On the Sendlinger Tor-Platz crowds seeking illegal trading opportunities reached from 800 to 1,500 persons. 
police to set up a special branch (Sonderabteilung) for fighting the black market. This unit began on September 1 under the direction of the new Police Chief Pitzer. At first it was comprised of a meager 32 officials -- for a city of over 560,000 registered citizens. 48

The special units contributed nevertheless to the apparent check on black market activity. Yet the ability of the Munich police to combat the black market was complicated by numerous dilemmas. Both the sheer numbers of black marketeers and their cleverness in finding new methods were difficult to control. MG restrained certain German proposals for fighting black trade. In late September, for example, a plan to declare it illegal, and punishable, for four or more persons to gather was rejected by MG. 49

German police authority enjoyed little respect. The following example serves as illustration. As early as July 19, 1945, a Munich police team -- 20 detectives and 25 patrolmen -. attempted a raid on the Viktualienmarkt. The raid was a disaster from the beginning. A large group of DPs approached the police vehicles before they even fully stopped, pulled policemen out and attacked them. The police, after rescuing a driver from the crowd and with a few suspects in custody, eventually fled the scene under a barrage of stones. The raid resulted in only six arrests and numerous wounded policemen. 50

48 Obermaier, and Maurer 73.

49 Boelke 94.

50Fuchs 116 . 
The policeman's truncheon proved scarcely effective against the more violent black marketeers. MG recognized this, 51 but initially stuck to its policy of putting off rearming the police. MG Public Safety Branch officials blamed the German police for not handling the truncheon effectively 52 and attempted to strengthen the black market units by calling for an increase in the number of personnel instead. Constant pressure from police chief Pitzer as well as the continuing incidents of police ineffectiveness eventually led MG to change its policy. 53

DPs proved an impossible challenge to German police. DPs were commonly the most violent black marketeers, and also had the least regard for German authority. German police assumed that most of the main traders had established permanent inventories, and believed the DP camps a major source. ${ }^{54}$ German officials had no jurisdiction over DPs, however, and could not enter their camps. This fact of life continued well past the first months. In describing the situation near the Deutsches Museum -- a prominant DP gathering spot and UNRRA camp -- the following Munich police report expresses the pronounced lack of leverage: 55 concern.

51 Munich MG reports for the fall of 1945 repeatedly expressed this ${ }^{52}$ Boelke 223.

53 Fuchs 116.

54Fuchs 115.

55 Report from July 17, 1946 qtd. in Boelke 96 (this author's translation). 
[DPs] believe that the German police are not allowed to intervene against them. When German police do take action against them, the DPs immedediately put up severe resistance, and do not back down. This is why intervention led to nasty incidents every day. Police were surrounded by packs, pelted with stones, and threatened to be thrown in the Isar [river]. When in an emergency policeman reach for the truncheon or the pistol, they are rudely insulted as "Nazi police." Even the threat of the pistol alone became impossible. When we attempted to check someone out for black market trading, hundreds of [DPs] came out of the UNRRAcamp to back the suspect. Only in a few cases were German police able to complete arrest and bring a suspect to the station. The assistance of the military police brought little real improvement, so that since May 1946 German patrols have discontinued activity in the area.

The inability of the German police to act in DP matters allowed the black market to flourish. The UNRRA camps, off limits to German police and due to a lack of personnel and authority out of the influence of MG, were a main source for this market. Relatively ample DP food rations frequently ended up as black market merchandise. A MG officer assigned to conduct a routine operations review of the Munich situation considered UNRRA management of DP food stocks "terrible:"56

The food leakage from the warehouse at Munich distributing food to DP camps is uncontrollable at the present time. It is well known that this source constitutes the greatest black market activity and the UNRRA officials are entirely responsible

The visiting officer regretted the fact that MG detachment personnel could not take a more active role in controlling the situation: 57

On account of redeployment it was necessary to curtail [MG's] checking of UNRRA operations because the Det ["detachment"] did not have the personnel. It is not known what the percentage of rations overdrawn is, but it is recognized that the black market

56 BayHStA OMGB(Y) CO/445/1, Op. Report, Dec. 19, 1945, 3.

57BayHStA OMGB(Y) CO/445/1, Op. Report, Dec. 19, 1945, 3. 
from this source is increasing and the Det has no additional officer personnel to assign this duty.

The premature victory over the black market in the fall of 1945 was in reality the beginning of an increasingly worsening situation. This MG assessment of January 1946 practically acknowledged as much:58

There is still a Black Market in operation in Munich. It has, however, gone underground and D.P.'s [sic] are the main culprits. German police have no influence with these DPs, and consequently UNRRA has its own police force to deal with them. In the last week 122 persons were arrested for Black Market, and 75 were D.P.s. These figures do not portray the true percentages of D.P's and Germans engaged in Black Market, however, as the German Police are not able to arrest most of the former.

Huge black market raids increased. Over 125 were conducted in 1946 , leading to 3,803 arrests. 59 Moreover, increasing crime rates necessitated concerted operations between MG, US military police and the German police. MG was forced to assist in problematic DP matters. On November 10, 1946, for example, MG conducted a major raid at the DP camp on the Leonrodstraße. 100 arrests were made, and numerous stocks of munitions and provisions obtained from US Army depots, pillaged goods, and black market items were seized. 60

The black market dillemas of 1945 constituted only the start of a major problem. Intensified enforcement and more effective police tactics did not address the human issues at the heart of much black market activity. Social and psychological problems such as hunger, fear, ill 1.

58 BayHStA OMGB(Y) 10/78-1/3, MG Monthly for January 1946,

${ }^{59}$ Chronik, 226.

${ }^{60}$ Chronik 210. 
regard and uncertainty would get much worse after 1945 before they improved. Only with the scant but promising optimism brought on by the Currency Reform of 1948 did the black market itself begin to wane. 


\section{CHAPTER VII}

\section{CONCLUSION}

It is a wonder US MG detachments achieved what they did under the complex and chaotic conditions they faced in the spring, summer, and fall of 1945. US MG revealed a checkered ability to establish its own authority and control affairs, but in an important area like Munich completed its goals with admirable efficiency. As MG gave up the constant and direct control of German affairs early in the occupation, it could only accomplish a limited amount. German authorities still had a long stretch of hardship and growth before they reached effective credibility and capability. The first year of the occupation constituted a purposeful beginning, but a precarious one as well.

The issues described in these pages were crucial, and greatly helped determine the course of the occupation and the directions of German postwar development. Formidable human suffering, supply concerns, infrastructure breakdown and the lack of credible German authority nagged at the efforts to begin anew. Fueled by anger, revenge, hunger, need and greed, threatening lawbreakers consistently challenged MG and German authorities' efforts to establish themselves. To a certain extent, only time could really heal many crime problems. Such critical issues could only be solved by fundamental improvements in the post-war environment; by stabilization of the food supply, a stable currency, a 
rejuvenated system and a hopeful populace. In 10 years' time from 1945 , US occupation authorities would still be commonplace in Southern Bavaria, yet the sorry state of things was much transformed. The horrific, chaotic conditions could not last indefinitely. The effects would, however, last lifetimes.

The period emphasized in this work constituted the "incubation stage" of postwar Germany. Modern Munich, Southern Bavaria, and all of Germany are today still very much direct progeny of those hard formative years. The aftermath of the century's most unforgiving war and the ensuing occupation led to results that were mostly new for Germans, in some aspects continuous with the pre-Nazi past, and in others remarkably akin to issues today. The German press has regained its identity, but that identity is today much closer to the Anglo-Saxon model than it was before the war. Modern German police do not still dress like Chicago policemen, nor are they directly responsible to their municipality as US planners intended them to be. Yet they do serve the citizens and they uphold their constitution, the Grundgesetz. Providing for masses of once enslaved Displaced Persons is no more a problem in Germany -- or is it? Despite recent laws, German officials and politicians grapple daily with a constant influx of refugees and asylum-seeking aliens. The sudden economic prosperity of the 1950s' Wirtschaftswunder dealt the final blow to many of the economic and social problems caused by the war and during the occupation period -- or did it? The examples, comparisons and questions go on ad infinitum, but the source is the same; the process was defined in the chaotic early months of the US occupation. 
In this "incubation stage" of the occupation the United States assumed the role of conqueror and was soon forced to grow into an international master. In assuring law and order, US officials were forced for the first time to fully assume the "world's policemen" role they are recognized for today. US Military Government experiences such as those detailed in these pages provided significant lessons for the new role.

These considerations bring us back to the introduction of this work, and what this thesis was meant to achieve. I sought to illustrate how US Military Government established authority and directed law and order in a given area, and determine the challenges involved. This work does not attempt to be the last word on this subject, but rather attempts to raise and define valid questions about it. Many researchable issues are raised in these pages, but the method of managing them is also an issue. This study puts them on the table. As it turned out, there were many challenges in attempting to document such a confused and volatile period and subject. Hopefully the effort offers some rewards in return. 
REFERENCES

\section{UNPUBLISHED DOCUMENTS}

Bayerisches Hauptsaatsarchiv München (BayHStA). Records of the Office of Military Government for Bavaria:

OMGB[Y] 9/18-1/4;10/51-3/2;10/65-1/5;10/77-3/1;10/78-1/3;

$10 / 78-1 / 4 ; 10 / 85-3 / 5 ; 10 / 92-1 / 24 ; 10 / 92-1 / 25 ; 13 / 142-1 / 7$; $\mathrm{CO} / 445 / 1 ; \mathrm{CO} / 449 / 2 ; \mathrm{CO} / 451 / 2$.

CONTEMPORARY NEWSPAPERS

Bayerische Landeszeitung. Nachrichtenblatt der Allierten 6. Heeresgruppe für die deutsche Zivilbevölkerung.

Münchner Zeitung. Alliertes Nachrichtenblatt für die deutsche Bevölkerung.

Süddeutsche Zeitung.

\section{PUBLISHED DOCUMENTS AND SECONDARY LITERATURE}

Allen, William Sheridan. The Nazi Seizure of Power: The Experience of a Single German Town 1922-1945. Rev. ed. New York: Franklin Watts, 1984.

Americans as Proconsuls: United States Military Government in Germany and Japan, 1944-1952. Ed. Robert Wolfe. Carbondale and Edwardsville: Southern Illinois University Press, 1984. 
Boehling, Rebecca. "German Municipal Self-Government and the Personnel Policies of the Local U.S. Military Government in Three Major Cities of the U.S. Zone of Occupation: Frankfurt, Munich, and Stuttgart." Archiv für Sozialgeschichte. 25 (1985): 333-383.

Boelke, Willi. Der Schwarzmarkt 1945-48: Vom Überleben nach dem Kriege. Braunschweig: Westermann, 1986.

Chronik der Stadt München 1945-48. Ed. Wolfram Selig. Munich: Stadtarchiv, 1980.

Clay, Lucius D. Decision in Germany. Garden City, New York: Doubleday and Company, 1950.

Davidson, Eugene. The Death and Life of Germany. New York: Alfred A. Knopf, 1959.

Davis, Franklin M. Jr.. Come as a Conquerer: The United States Army's Occupation of Germany 1945-49. New York: Macmillan, 1967.

Deutsche Presse seit 1945. Ed. Harry Pross. Bern: Scherz, 1965.

Documents on Germany, 1944-1985. Office of the Historian, Department of State: Washington, D.C., 1986.

Frei, Norbert. Amerikanische Lizenzpolitik und deutsche Pressetradition. Die Geschichte der Nachkriegszeitung Südostkurier. Munich: Oldenbourg, 1986.

Friedrich, Carl J., et al. American Experiences in Military Government in World War II. New York: Rinehart \& Company, 1948.

Gimbel, John. The American Occupation of Germany: The Politics and the Military, 1945-49. Stanford: Stanford University Press, 1961 .

Gullion, Allen W. (Provost Marshal General). "Military Government." Coast Artillery Journal. 86 (1943): (pgs. n/a).

Habe, Hans. Im Jahre Null: Ein Beitrag zur Geschichte der deutschen Presse. Munich: Verlag Kurt Desch, 1966. 
Handbuch der bayerischen Ämter, Gemeinden und Gerichte 1799-1980.

Ed. Wilhelm Volkert. Munich: C.H. Beck'sche

Verlagsbuchhandlung, 1983.

Hartenian, Larry. "The Role of Media in Democratizing Germany:

United States Occupation Policy 1945-49." Central European

History. $198720(2): 145-190$.

Holborn, Hajo. American Military Government. Its Organization and Policies. Washington, D.C.: Infantry Journal Press, 1947.

Hurwitz, Harold. Die Stunde Null der deutschen Presse. Die Amerikanische Pressepolitik in Deutschland 1945-49. Cologne: (publisher n/a), 1972.

Flüchtlinge und Vertriebene in der Westdeutschen Nachkriegsgeschichte: Bilanzierung der Forschung und Perspektiven für die künftige Forschungsarbeit. Ed. Rainer Schulze, Doris von der BrelieLewien, Helga Grebing. Hildesheim: Lax, 1987.

Kempner, Robert M. W. "Amerikanische Militärgerichte in Deutschland." Die Freiheit des Anderen. Baden-Baden: Nomos Verlags-Gesellschaft, 1981, 145-163.

Krieger, Leonard. "The Inter-Regnum in Germany: March-August 1945." Political Science Quarterly. 44.4 (1949): 507-532.

Krieger, Leonard. "The Potential for Democratization in Occupied Germany." Public Policy. ed. John D. Montgomery and Albert O. Hirschman. vol. 17. Cambridge, MA: Harvard University Press, 1968, 28-58.

Litchfield, Edward H., and Associates. Governing Postwar Germany. Ithaca, NY: Cornell University Press, 1953.

Matz, Elisabeth. Die Zeitungen der US-Armee für die deutsche Bevölkerung (1944-46). Münster: Verlag C.J. Fahle, 1969.

Minott, Rodney G. The Fortress That Never Was. New York: Holt, Rinehard and Winston, 1964.

Niethammer, Lutz. "Die amerikanische Besatzungsmacht zwischen Verwaltungstradition und politischen Parteien in Bayern 1945." Vierteljahreshefte für Zeitgeschichte. 15.2 (1967): 153-210.

- - Entnazifizierung in Bavern: Säuberung und Rehabilitation unter amerikanischer Besatzung. Frankfurt a. M.: S. Fischer, 1972. 
NS-Deutsch. "Selbstverständliche Begriffe und Schlagwörter aus der Zeit der Nationalsozialismus. Ed. Karl-Heinz Brackmann and Renate Birkenhauer. Straelen: Straelener Manuskripte Verlag, 1988.

Obermaier, Franz, and Mauerer, Josef, Aus Trümmern wächst das Neue Leben. Munich: Neue Münchner Verlags-Gmbh, 1949.

Padover, Saul K. Experiment in Germany. New York: Duell, Sloan and Pearce, 1946.

The Papers of General Lucius D. Clay: Germany 1945-1949. Ed. Jean Edward Smith. 2 vols. Bloomington: Indiana University Press, 1974.

Peterson, Edward N.. The American Occupation of Germany: Retreat to Victory. Detroit: Wayne State University Press, 1977.

- - The Limits of Hitler's Power. Princeton, NJ: Princeton University Press, 1968.

Richardi, Hans-Günter. "Bejubelt -- doch von der Geschichte übersehen.” Süddeutsche Zeitung [Munich] 8 Oct. 1993, 47.

Rinderle, Walter and Norling, Bernard. The Nazi Impact on a German Village. Lexington, KY: The University Press of Kentucky, 1993.

Schmidt, Hans Theodor. "Das Strafrecht in Deutschland nach der Kapitulation." Deutschland Archiv. 1971 4, 43-47.

Schwartz, Thomas Alan. America's Germany: John J. McCloy and the Federal Republic of Germany. Cambridge, Mass: Harvard University Press, 1991.

Smith, Jean Edward. Lucius D. Clay: An American Life. New York, Henry Holt and Company, 1990.

Trümmerleben. Texte, Dokumente, Bilder aus den Münchner Nachkriegsjahren. Ed. Friedrich Prinz and Marita Krauss. Munich: Deutscher Taschenbuch Verlag, 1985.

Trümmerzeit in München. Kultur und Gesellschaft einer deutschen Großstadt im Aufbruch 1945-49. Ed. Friedrich Prinz. Munich: Beck, 1984.

UNRRA: The History of the United Nations Relief and Rehabilitation Administration. Ed. George Woodbridge. 3 vols. New York: Columbia University Press, 1950. 
Von Stalingrad zur Währungreform: Zur Sozlalgeschichte des Umbruchs in Deutschland. Ed. Martin Brozsat, Klaus-Dietmar Henke and Hans Woller. Munich: Oldenbourg, 1988.

Wagner, Dieter. München ' 45 zwischen Ende und Anfang. Munich: Süddeutscher Verlag, 1970.

Ziemke, Earl F. Army Historical Series: The U.S. Army in the Occupation of Germany, 1944-1946. Washingtion, D.C.: United States Army Center of Military History, 1975.

US Army Historical Division, Headquarters European Command. Military Government in Munich 1945-1947. Vol. 1. Special Studies Series 3. N.p.:1951.

US Occupation in Europe after World War II: Papers and Reminisces from the April 23-24, 1976, Conference Held at the George C. Marshall Research Foundation, Lexington, Virginia. Lawrence: The Regents Press of Kansas, 1978.

Woller, Hans Gesellschaft und Politik in der amerikanschen Besatzungszone: Die Region Ansbach und Fürth (Munich: Oldenbourg, 1968).

Zink, Harold. The United States in Germany 1944-45. Princeton: Van Nostrand, 1957. 